\title{
Kent Hakkı Bağlamında Endüstri Mirasını Yeniden Okumak: TÜRASAŞ Eskişehir Örneği
}

*

\author{
Ebru Yetkin ${ }^{1}$ \\ ORCID: 0000-0001-9614-0355
}

\author{
Esin Boyacioğlu² \\ ORCID: 0000-0001-7407-1336
}

\author{
Ayşe Duygu Kaçar ${ }^{3}$ \\ ORCID: 0000-0002-6561-7517
}

\section{Öz}

Endüstri mirasının geleceğine ilişkin karar süreçlerinde kentlinin taleplerini geri plana iten, belirli bir kesimin çıkarlarını gözeten ve maddi getirilerin önemsendiği yaklaşımların hâkim olduğu görülmektedir. Bu çalışmada endüstri mirasının korunmasında sıklıkla göz ardı edilen kentlileri ve tercihlerini hatırlatmak adına TÜRASAŞ Eskişehir yerleşkesi, kent hakkı kavramı bağlamında irdelenmiştir. Çünkü endüstri mirası kolektif biçimde üretilen bir yapıttır (oeuvre). Literatürdeki çalışmalar, çoğunlukla endüstri mirasının işlevini kaybettiği döneme ve bu aşamadan sonra yapılabileceklere odaklanmaktadır. Iş̧lev yitiminin ardından, "mirastan kalanlar ile ne yapılacă̆g" ve "bu kararı kimin vereceği" soruları gündeme gelmektedir. Özgün işlevini sürdüren ancak çeşitli baskılar ile karşı karşıya kalan bir endüstri mirası özelinde kent hakkının tartışılması, bu soruların yanıtlarını üretebilmek için önemlidir. Illk olarak, mirasın kent toplumunun oluşumundaki etkileri araştırılmıştır. İkinci olarak, mirasın somut ve somut olmayan değerlerini oluşturan bu etkiler, Lefebvre'in kent hakkı perspektifi üzerinden iki ana başlık altında ele alınmaktadır: özyönetim ve sahiplenme. TÜRASAŞ Eskişehir ve kentli arasında kısıtlı bir etkileşimin sürdüğ̈̈, kentlinin mirası sahiplendiği görülmüştür. Bu noktada çalışma, endüstri mirasının geleceği konusunda özgün bir kavramsal çerçeve sunmaktadır. Miras ve kentli arasındaki iletişimi güçlendirmek için kimi somut adımların atılması önerilmiştir. Bu iletişim geliştikçe kentlinin mirasa ilişkin farkındalığının artacă̆ı ve daha güçlü bir kent hakkı talebi geliştireceği öngörülmüştür.

Anahtar Kelimeler: Kent hakkı, kent toplumu, endüstri mirası, Eskişehir, TÜRASAŞ Eskişehir.

Bu çalışma, Prof. Dr. Esin Boyacıoğlu'nun ve Doç. Dr. Ayşe Duygu Kaçar'ın danışmanlığında Ebru Yetkin tarafından Gazi Üniversitesi, Fen Bilimleri Enstitüsü, Mimarlık Ana Bilim Dalı'nda yazılan doktora tezine yönelik yapılan araştırmalar sonucunda üretilmiştir.

${ }^{1}$ Arş Gör., Eskişehir Osmangazi Üniversitesi, E-mail: eyetkin@ogu.edu.tr

${ }^{2}$ Prof. Dr., Gazi Üniversitesi, E-mail: eboyacioglu@gmail.com

${ }^{3}$ Doç. Dr., Eskişehir Osmangazi Üniversitesi, E-mail: duygukacar@hotmail.com

idealkent (c) Kent Araştırmaları Dergisi (Journal of Urban Studies)

http://idealkentdergisi.com

Geliş Tarihi Received Date: 15.07.2021 Kabul Tarihi Accepted Date: 27.09.2021 


\title{
Reevaluating the Industrial Heritage in the Context of the Right to the City: The Case of TÜRASAŞ Eskişehir
}

\author{
Ebru Yetkin 4 \\ ORCID: 0000-0001-9614-0355
}

\author{
Esin Boyacioğlu ${ }^{5}$ \\ ORCID: 0000-0001-7407-1336
}

\author{
Ayşe Duygu Kaçar6 \\ ORCID: 0000-0002-6561-7517
}

\begin{abstract}
Regarding the future of the industrial heritage, main approaches exclude the wishes of inhabitants, take into account interests of a specific part of society, attach importance to profits. The concept of right to the city has been researched on TÜRASAŞ Eskişehir in order to remind the inhabitants and their demands neglected in the conservation of industrial heritage. Because industrial heritage is a collectively produced artwork(oeuvre). Literature mostly focusses on the period when industrial heritage lost its function. After functional loss, the questions of "what to do with the remains" and "who will make decisions" become current issue. It's important to discuss the right to the city for industrial heritage that maintains original function but faces pressures, in order to produce answers to these questions. First, the effects of heritage on the formation of urban society were investigated. Secondly, these effects, which can be seen as the tangible and intangible values, are discussed under two main headings in the context of the right to the city from Lefebvre's perspective: self-management and appropriate. Although there is a limited interaction between TÜRASAŞ Eskişehir and inhabitants, it has been determined that they appropriate the heritage. At this point, study offers a unique conceptual framework for the future of heritage.
\end{abstract}

Keywords: Right to the city, urban society, industrial heritage, Eskişehir, TÜRASAŞ Eskişehir.

\footnotetext{
${ }^{4}$ R.A., Eskişehir Osmangazi University, E-mail: eyetkin@ogu.edu.tr

${ }^{5}$ Prof. Dr., Gazi University, E-mail: eboyacioglu@gmail.com

${ }^{6}$ Assoc. Prof. Eskişehir Osmangazi University, E-mail: duygukacar@hotmail.com

idealkent (c) Kent Araştırmaları Dergisi (Journal of Urban Studies) 


\section{Giriş}

Kültürel miras kapsamındaki endüstri mirasına yönelik geliştirilen dönüşüm stratejilerinin sorgulanması gerekmektedir. Endüstri mirası niteliğine sahip alanlar günümüzde kent merkezinde kalmaları, sahip oldukları geniş araziler, mülkiyet sorunları, kentsel rant gibi etkenler nedeniyle karar vericiler tarafından sıklıkla birer meta olarak görülmektedir. Bu bakış mirasın geleceğine ilişkin karar ve dönüşüm süreçlerinde kentlinin çıkarlarını, taleplerini geri plana itmekte hatta yok saymaktadır. Mirasın kaybedilmemesi ve korunması adına gelişen tartışmaların çoğunlukla endüstriyel yapının/yerleşkenin işlevini yitirmesinden, çöküntü alanına dönüşmesinden sonraki döneme odaklandığı gözlemlenmiştir. Bu nedenle önerilen projeler, yapılan araştırmalar ve akademik çalışmalar yeniden kullanım, yeniden işlevlendirme, endüstri mirasının dönüşümü gibi kavramları, işlev yitimi sonrası mümkün olan olasılıkları ve optimum çözümleri tartışmaktadır.

İşlevini hâlen sürdüren ve endüstri mirası niteliğine sahip olan alanlar da sözü geçen etkenler nedeni ile çeşitli baskılara ve tehditlere maruz kalabilmektedir. Barındırdığı değerler ile gelişimini sürdüren, kent/kentli ile iletişimi henüz aktif olan endüstriyel mirasların incelenmesi mevcut olasılıkların ve tartışmaların ötesinde senaryoların gelişmesini sağlayabilir. Mirasın geleceğine yönelik asıl karar verici mekanizmanın onu üreten kentliler olması gerektiğini hatırlatmak, bu bağlamda mirasın somut ve somut olmayan değerlerini tespit edebilmek için şehir hakkı/kent hakkı kavramı ${ }^{7}$ çalışmanın odak noktasına alınmıştır. Çalışma, işlevini sürdüren bir endüstri mirasının kent hakkı çerçevesinden nasıl irdelenebileceğini araştırmaktadır. Kavramla ilintili olarak mirasın öne çıkan niteliklerini deşifre etmek, olası bir dönüşüm veya adaptasyon sürecinde gözetilmesi gereken unsurlara yönelik kavramsal bir zemin oluşturmak amaçlanmıştır.

İlk olarak Henri Lefebvre tarafından öne sürülen kent hakkı kavramı kent toplumunun kolektif biçimde yeni bir şehri, başka koşullarda hayal edebilmesi ile ilişkilidir (Lefebvre, 2016, s. 120). "Şehir hakkl, basit bir ziyaret etme ya da geleneksel şehirlere geri dönme aracı olarak düşünülemez. Sadece dönüşmüş, yenilen-

\footnotetext{
${ }^{7}$ Henri Lefebvre tarafından 1967 yılında yazılan "Le droit â la ville" adlı eserin, Işık Ergüden tarafından yapılan çevirisinde (Şehir Hakkı, 2016, s.118), yazar "ville (şehir) ve urbain (kent/kentsel) terimlerini" ayrıştırdığı için eserin orijinaline sadık kalındığı ve "şehir hakkı" teriminin tercih edildiği not düşülmüştür. Ancak Türkçe literatürde "kent hakkı ve şehir hakkı" kavramlarının eş anlamda kullanıldığı belirtilmiştir. Türkçe yazında ve alan özelinde sıklıkla tercih edilmesi nedeniyle çalışmada "kent hakkı" olarak anılmıştır.
} 
miş kentsel yaşam hakkı olarak formüle edilebilir" (Lefebvre, 2016, s. 132). Lefebvre'e göre şehir, kentsel gerçeklik, kent toplumu kullanım değeri ile öne çıkan birer oeuvre yani yaptt (2000, s.66; 2016, s.21-22,24, 121) iken kent bir üründür ve mübadele değeri ile öne çıkmaktadır (2014, s.23-24; 2016, s.132). Bu tanımdan hareketle çalışma kapsamında endüstri mirası da kent toplumunun oluşumunda önemli roller üstlenen bir yapıt olarak yorumlanmıştır. Hatta işlevini sürdürmesi nedeniyle özgün niteliklerinin çeşitlenerek arttı̆̆ı, sürekli gelişmesi nedeniyle henüz tamamlanmamış, kolektif biçimde üretilmeye devam eden bir yapıt olduğu söylenebilir.

Endüstri mirasının korunması ve geleceğe aktarılması süreçlerinde mirasın bir metaya dönüşmemesi için kent hakkı kavramının öncelenmesi gerektiğini savunan bu çalışma, Lefebvre'in bakışını temel almaktadır. Lefebvre'in özgün kent hakkı tanımı politik, salt fiziksel çeore ile sinurlanmayan, bireylerin/toplulukların yoksunlukları ve eşitsizliklerinin ortadan kaldırılmasını içeren, kentin hali hazırdaki durumuna dahil olmakla yetinmeyen yeni bir kentsel yaşamı kurma talebini işaret etmektedir (Marcuse, 2014). Kavrama ilişkin gelişen görüşler özgün kent hakkı tanımı kadar radikal olamadıkları, kavramın gerçek anlamını yitirmesine neden oldukları, bu hakkı mevcut kente ve onun sorunlarına indirgedikleri gibi eleştiriler alabilmektedir (bkz.: Mayer, 2011; Souza, 2010; Uzunçarşılı Baysal, 2011) veya daha çok kentli haklarının ilgi alanına dahil olabilmektedir. Kentli hakları devlet tarafından sunulması gereken hizmetlere ve tanınması gereken haklara, insan haklarına yönelik bir kavram olarak karşımıza çıkmaktadır. Öner ve Osmanoğulları (2017), kentli haklarını ve kent hakkını, temellendikleri farklı politik görüşler nedeni ile karşıt mefhumlar olarak görmektedir. Sadri (2005, s.84) ise kentli hakları özelindeki fikirleri ve atılan adımları, Lefebvre tarafından tanımlanan kent hakkına erişmek için bir uğrak noktası olarak yorumlamaktadır. Bu adımların asıl hedefe erişene kadar sürdürülmesi gerektiğini savunmaktadır.

Çalışma, geçmişten bugüne endüstri kenti olarak anılan Eskişehir'de, işlevini hâlen sürdüren ve kentin en köklü endüstri kuruluşu olan TÜRASAŞ Eskişehir Bölge Müdürlügü̈ (Türkiye Raylı Sistem Araçları Sanayii Anonim Şirketi) yerleşkesine odaklanmaktadır. Öncelikle kent hakkı ve endüstri mirası ilişkisi irdelenmiştir, kavramsal çerçeve kapsamında örneklem alanını analiz etmeyi mümkün kılan alt başlıklar belirlenmiştir. Örneklem alanının analizi iki aşamada gerçekleşmektedir. İlk aşama, kent toplumunun oluşumundaki etkileri yani mirasın kuruluşundan bugüne kent/kentli ile etkileşiminden türeyen, onu bir yapıt haline getiren somut/somut olmayan değerlerinin deşifre 
edilmesidir. İkinci aşama ise kent hakkı kapsamında, deşifre edilen değerlerin ve mirasin potansiyellerinin, problemlerinin yorumlanmasıdır. Kentin mevcut sosyokültürel ve politik durumu, karar vericilerin mirasa bakışından kaynaklanan, bu nedenle meta olarak görülmesine yönelik veya kentli hakları açısından gündeme gelen güncel olaylara, söylemlere, görüşlere de değinilmiştir. Bunların Lefebvre'in kent hakkı tanımından farkları irdelenmiştir. Literatür araştırması, arşiv taraması, yerinde gözlem teknikleri ile toplanan veriler örneklemi analiz etmeyi ve durum çalışması (örnek olay incelemesi) metodunu kullanmayı olanaklı kılmıştır. Örneklem alanı özelinde zamansal, bağlamsal ve kavramsal sınırlar belirlenmiştir. Mirasın kuruluşundan bugüne geçen tarihsel süreç zamansal sınırı; kent/kentli ile geliştirdiği fiziksel, mekânsal, sosyokültürel etkileşim bağlamsal sınırı; kent hakkı kavramı açısından değerlendirilmesi ise kavramsal sinırı oluşturmaktadır.

Sonuçta kent hakkının sınırları içerisinde, işlevini sürdüren bir endüstri mirasının geleceğine yönelik karar süreçlerinde hangi unsurların ve aktörlerin etkin olması gerektiğine dair bir tartışma yürütülmüştür. Bu tartışmanın endüstri mirasının korunması aşamasında sözü edilen problemlerin önüne geçmek için önemli bir başlangıç noktası olduğu öngörülmüştür. Çalışma, endüstri mirasının bağlamı ile ilişkisini kent hakkı üzerinden güçlendirmeyi hedeflemesi ve işlevini hâlen sürdüren bir alanı irdelemesi yönünden özelleşmekte ve literatüre özgün bir katkı sunmaktadır. İşlev yitimi gibi kritik bir eşikten önceki sürece odaklanılması önemli bulunmaktadır. Çünkü mirasın işlevini yitirmesi ve terk edilmesi sonucunda kimi değerleri yok olmakta, kentli ile etkileşimi büyük ölçüde zedelenmekte ve kentte problemli bir alan olarak değerlendirilme ihtimali artmaktadır. Bu aşamadan sonra belirli bir kesimin çıkarlarını gözeten dönüşüm projeleri daha kolay meşrulaştırılabilmektedir. Kent hakkı kavramının endüstri mirası özelinde incelenmesi ve bir örneklem alanı üzerinden yorumlanması kavramın bütüncüllüğünü, geniş kapsamını yadsımamaktadır. Çalışma, mirasa ilişkin güncel problemlerin çözümünde onu kolektif biçimde var eden, sahiplenen kentlinin tercihleri ve taleplerinin öncelenmesi bağlamında bir hatırlatma niteliği taşımaktadır.

\section{Kent Hakkı ve Endüstri Mirası İlişkisi}

2000'li yıllardan itibaren, kapitalist kentleşme süreçlerinin baskın hale gelmesiyle kent hakkına olan ilgi artmıştır (Çavuşoğlu ve Strutz, 2011). Lefebvre'e göre, kapitalizmin güçlenmesi ve küresel yayılım sağlaması sonucunda kentteki ürün üretimi, yapıt üretiminin ve bu yapıtlara bağlı toplumsal ilişkilerin yerini almıştır. Ürünün ve mübadele değerinin (alınıp satılan mekânlar, ürünler, 
mallar, yerler ve işaretlerin tüketimi) öne çıkışı ile kentin de meta haline gelmesi ve sanayi öncesi kentinin kullanım değerini (şehir hayatı, kentsellik ve kent zamanı) kaybetmesi konusuna dikkat çekilmiştir. Kentin kolektif biçimde üretilen ve yaşamı örgütleyen bir yapıttan ziyade, ürüne dönüşümü söz konusudur. Kapitalizm sonrası gelişen tüketim toplumunun öncelikleri yerine, güncel kent toplumuna dair ihtiyaçlar yeniden tanımlanmalı ve karşılanmalıdır (Lefebvre, 2016, s.21-24,45,119). Lefebvre için sanayileşmeden doğan toplum kent toplumudur ve toplumun bir bütün halinde kentleşmesi savı ile farklı niteliklere sahip tüm şehirleri işaret etmektedir (Lelefebvre, 2015, s.7-8). Sanayileşmeden önce var olan şehir, küresel ölçekte yayılan sanayileşme ve kentleşme ile birlikte dönüşerek, yerini kent toplumuna yani kentlere bırakmıştır (Lefebvre, 2015, s.10,21; Lefebvre, 2016, s.21).

Sonuçta her şeyin alınıp satılabildiği, sahtesinin üretilebildiği bir durumda (Lefebvre, 2016, s.132-133) kent hakk1, "özgürlük hakkl, toplumsallık içinde bireyleşme hakkl, habitat ve mesken hakkl, yapıt hakkl, katıllm ve sahiplenme hakkı" gibi hakları da kapsayan derin ve üstün bir hak olarak doğmaktadır (Lefebvre, 2016, s.151). Kimi zaman birbiri ile çelişen kimi zaman birbirini tamamlayan her tür temel ve özelleşmiş ihtiyaç kent hakkına dahildir (Lefebvre, 2016, s.119). Burada işaret edilen ve sınırları belirgin olmayan kent hakkı yeni bir yaşam biçimi kurabilmek, kolektif biçimde inşa edilen kenti dönüştürme hakkı ve gücünü elde etmektir.

Lefebvre'in görüşlerinin sürekliliğinde Harvey (2013, s.45), bu kolektif hakkı talep etmenin ve kentlerin yeniden şekillendirilmesi konusunda gücü ele geçirmenin önemi üzerinde durmuştur. Harvey'e göre, bireyin/tüm kentlinin, kentte bulunan temel kaynak ve ihtiyaçlara erişim hakkından çok daha fazlası gündeme gelmelidir (Harvey, 2013, s. 44).

Souza (2010), kent hakkına yönelik güncel düşünüm ve hareketlerin, Lefebvre tarafından kurulan çerçeveden başladığını ama onunla eş derinlikte ele alınmadığını savunmaktadır. Otoriter yönetim, konut sorunu, soylulaştırma gibi sorunların karşısında durmak ve şartları iyileştirmek tek başına yeterli değildir. Mevcut sistemi bu sorunların temel sebebi olarak ele almak ve köklü dönüşümleri başlatmak esastır (Souza, 2010).

Kent hakkının özgün tanımına dönüldügünde, aslında Lefebvre sonrasında gelişen yaklaşımları ve kentli haklarını kapsadığı söylenebilir. Örneğin, son dönemde kolektif olan ve dayanışma hakları olarak nitelendirilen "çevre hakkl, toplumsal ve kültürel self-determinasyon (kendi kaderini belirleme), insanliğın ortak varlığından faydalanma, barış içinde yaşama" gibi üçüncü kuşak hakları 
(Tekeli, 2015, s.186-187) kapsamaktadır. Tekeli'nin görüşlerinden yararlanarak, çalışma kapsamında endüstri mirası ile ilişkilenen temel haklar şu şekilde sıralanabilir: Ekolojik dengeye sahip, aidiyet duygusu geliştirilebilecek bir kimliği olan, nitelikli mimari ögelere/kültürel varlıklara sahip ve bu doğrultuda gelişimini sürdüren, gerekli altyapı sistemlerinin kurulduğu, yeterince yeşil alanı olan, eğitim ve kendini geliştirme imkanları sunan, yönetim biçimini seçme/katılma/denetleme firsatı veren, yeterince ve nitelikli çalışma güvencesi veren, üretilen artı değerden pay alınabilen bir kentsel çevrede yaşama hakk1 (Tekeli, 2015, s.188-189). Bu kapsamda kültürel mirasa ait değerlere erişim hakkından da söz etmek mümkündür; herkese ait bir haktır ve bu anlamda bireylerin birbirlerine karşı sorumlulukları vardır. Kültürel miras tanımı belirli bir topluluk veya topluma atfedilmeden, ortak bir değer olarak görülmeli ve herkesi kapsayacak biçimde ele alınmalıdır (Hodder, 2010). Lefebvre'in kent hakkı tanımı ile sözü geçen kentli hakları arasındaki temel fark şudur: İnsan hakları veya kentli hakları mevcut politik düzeni kabul ederek yöneticilerden talep edilen, devletin sunması gerektiği düşünülen unsurlardır. Oysa Lefebvre bu hakların da ötesini işaret etmekte ve sistemin kökten değiştirilmesini içeren, karar verici mekanizmanın kentte yaşayanlar tarafından elde edildiği bir kent hakkı önermiştir.

Kentin sahip olduğu çatışmalar kent hakkı ve kentli haklarının sıklıkla gündeme gelmesine yol açmaktadır. "Sanayileşme ve kentleşme, büyüme ve gelişme, ekonomik üretim ve toplumsal yaşam" ikilikleri hem birlik içinde hem de çatışmalıdır (Lefebvre, 2016, s.26-27). Sanayileşmenin başlangıcından modern kentin oluşumuna dek süregelen bu çatışma, kentin ve kentlinin sorunlarının temelini oluşturmaktadır. Toprak spekülasyonu, kentin hızlı ve plansız büyümesi, ticari ve endüstriyel çöküntü alanlarının oluşması, kentsel dönüşüm uygulamaları, eski kentten kalan anıtların tüm anlam ve değerlerinden arındırılarak salt tüketim nesnesi haline dönüştürülmesi, kimlik yitimi gibi durumlar bu sorunlara örnek gösterilebilir.

Kentsel dönüşüm, yenileme projeleri kent hakkı kavramının hatırlanması ve bu projeler bağlamında gündeme getirilmesi ihtiyacını doğurmaktadır. Harvey'e göre (2013, s.58-66) yıllar içinde oluşan toplumsal bütünlük ve kentsel dokuyu yıkan dönüşümler, arazi piyasasının gelişmesi ve maksimum kazancın sağlanması için bir araç olarak görülmüştür. Tekeli'ye göre (2015, s.5758), özellikle 20. yüzyılın ikinci yarısından itibaren hız kazanan kentsel yenileme projeleri iki temel durum ile gerekçelendirilmektedir. Birincisi, kent merkezinde oluşan ve suç kaynakları olarak görülen çöküntü alanlarından 
kurtulma çabasıdır. İkincisi, işlevini görece yitiren endüstriyel alanların dönüştürülmesidir. Endüstri mirasına yönelik yaklaşımlar sözü geçen her iki duruma da dahil olabilmektedir. Mirasının dönüşümünde çoğunlukla alanın sahip olduğu rant değeri gözetilerek belirli bir kesimin faydalanabileceği, onların ihtiyaçlarına yönelik uygulamalar karar vericiler tarafından tercih edilmektedir. Böylece dönüşüm alanında veya çevresinde yaşayanların barınma sorunları ve soylulaştırma (Mengüşoğlu ve Boyacıŏlu, 2013), endüstri mirası niteliği taşıyan yapı ve yerleşkelerin değerlerini yitirmesi, kültürel mirasın bir meta gibi ele alınarak belirli bir kesimin yararına dönüştürülmesi gibi olumsuz sonuçlarla karşılaşılmaktadır.

Endüstriyel alanlar 20. yüzyılın sonlarında, değişen teknolojiler ve mekânsal ihtiyaçlar karşısında işlev yitimine uğrayarak atıl alanlara dönüşmeye ve hızlı endüstrileşme dönemindeki önemini kaybetmeye başlamıştır (Cengizkan, 2006; Mengüşoğlu ve Boyacıoğlu, 2013). Toplumsal yapıyı ve kentsel çevreyi şekillendiren endüstriyel yerleşkeler çoğunlukla üretimin organizasyonundan satış işlemine, kentle olan ilişkisinden atık ve peyzaja olan etkisine kadar örgütlenmiş, sistematik işleyen alanlardır (Stuart, 2012, s.48). Sanayileşme öncesi doğal çevre ile ilişkili insan üretimi yerleşimler olarak tanımlanabilecek peyzaj tanımı, iki yüzyılı aşkın süredir endüstriyel donatıların eklemlenmesi ile farklılaşmıştır. Endüstri mirasının bağlamı ile birlikte irdelendiği, somut değerlerin yanı sıra kültürel etmenleri de ele alan geniş kapsamlı bir tanıma erişilmiştir (Palmer ve Neaverson, 2001, s.16).

Bugünden bakıldığında endüstri mirasının, kent toplumunun oluşumunda etkin rol aldığı görülmektedir. Kentin oluşumu, kendine ait yapı veya yerleşkelerin gelişimi, kentsel yaşamın dönüşümü (mekânsal, sosyokültürel, politik, ekonomik açıdan) süreçlerinde kentli ile etkileşim halinde olmuştur. Bu etkileşimden doğan değerler ise kent hakkı kapsamında sahiplenme, geleceğini planlama, yeniden üretme, dönüştürme, hatırlama gibi talepleri gündeme getirebilir.

Çalışma alanı olarak TÜRASAŞ Eskişehir Bölge Müdürlügü̈ne ait yerleşke seçilmiştir. Yerleşke, somut ve somut olmayan tüm değerleri (mekânsal nitelikleri, özgün mimari unsurları, kent/kentli ile olan ilişkisi, tanıklık ettiği tarihsel süreç) ile birlikte endüstri mirası, demiryolu mirası, endüstriyel peyzaj gibi farklı alt tanımlara dahil olabilecek niteliktedir. Bugün, yerleşkenin kent merkezinde kalması ve sahip olduğu geniş arazi büyük bir rant üretmektedir. Dolayısıyla dönüşümü veya taşınması hususunda baskılar, çeşitli spekülasyonlar ortaya çıkmaktadır. Yerleşkeye erişimin kısıtlanması sonucu kentten ve kentliden kopması, fiziksel yayılım ihtiyacı, ulaşımda yaşanan problemler 
gibi nedenler ile tesisin taşınması zaman zaman gündeme getirilmektedir (Yerel basından örnekler: İstikbal Gazetesi, 2019; Seda, 2012).

\section{TÜRASAŞ Eskişehir Yerleşkesi: Önemi ve Kent Hakkı Bağlamında İrdelenmesi}

Yerleşke, ölçeği itibarıyla bir kent parçası, özgün mekânsal nitelikleri ve donatıları ile bir endüstriyel peyzaj ve yüz yılı aşkın süredir toplumun, kentlinin dönüşümünde önemli etkileri olan kültürel bir değer olarak tanımlanabilir. 1894 yılında Almanlar tarafından "Anadolu-Osmanl Şimendifer Kumpanyası" adıyla kurulan (Yatağan, 2013, s.92) ve sadece bakım-onarım görevlerini üstlenen bir atölyeden, demiryolu endüstrisi kapsamında pek çok üretimi yapabilecek bir endüstriyel yerleşkeye dönüşmüştür. Köklü tarihi boyunca kentin ve kentlinin dönüşmesinde en önemli etkenlerden biri olmuştur. Bu başlık altında öncelikle Eskişehir özelinde, TÜRASAŞ'ın kent toplumunun oluşumundaki etkileri irdelenmiştir. Çalışmanın devamında mirasın ürettiği etkilerin, sahip olduğu değerlerin kent hakkına yansımaları yorumlanmıştır.

\section{Kent Toplumunun Oluşumundaki Etkileri}

Eskişehir özelinde irdelenen bu etkiler kentsel bă̆lam, yerleşkenin gelişimi, yaşam biçimi, üretim, eğitim, kurum kimliği ve niteliği başlıkları altında araştıılmış, ürettiği değerler deşifre edilmiştir.

\section{Kentsel bağlam}

19. yüzyılda ağırlıklı olarak tarımla geçinen Eskişehir (Keleş, 2008), Osmanlı'nın son dönemlerinde endüstri ile tanışmıştır. 1892 yllında Haydarpaşa'dan hareket ederek Eskişehir'e ulaşan ilk tren (Koylu, 2015, s.15) ve aynı yıl tamamlanan İzmit-Eskişehir hatları (Christensen, 2017, s.16) ile kentin demiryolu bağlantısı sağlanmıştır. 1892' de inşa edilen gar binası kent için modern bir fonksiyon tanımlamış, yeni bir toplanma alanı önermiştir (Yatağan, 2013, s.110). Demiryolunun kente gelişinden sonra özellikle gar ve Porsuk çevresinin gelişimi hızlanmıştır (Ertin, 1994, s.17).
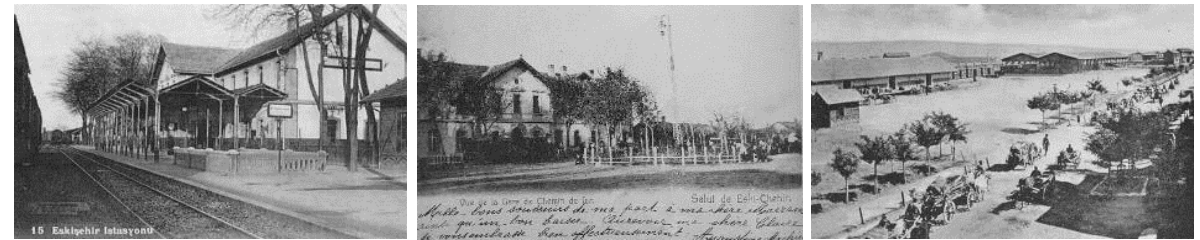

Şekil 1-2. Eski garın peron ve yol cepheleri (Koylu, 2015, s.63; Sarı̈z, 1997, s.70).

Şekil 3. Eskişehir Garı Ulaştırma Binaları (Koylu, 2015, s.54). 

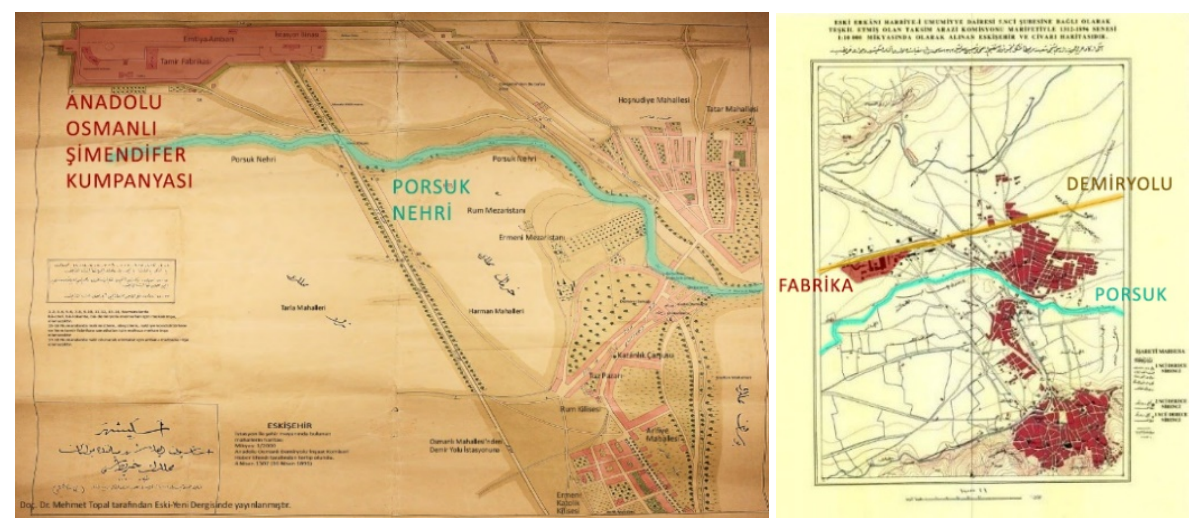

Şekil 4. 1891 yılında Eskişehir İstasyonu ve yakın çevresi (Koylu ve Birgün, 2015, s.17). Şekil 5. 1896 yılında Eskişehir yerleşim planı (Kaçar ve Alpan, 2018, s.89): Güneyde ilk yerleşim bölgesi Odunpazarı, kuzeyde göçmen mahallesi arasında kent merkezi bulunmaktadır (Görsellerde fabrikanın alanı ve Porsuk Nehri vurgulanmıştır).

Eskişehir, karayoluna göre hızlı bir alternatif olan demiryolu ve İstanbul'a erişimin kolaylaşması sayesinde ticari fonksiyonunu geliştirmiştir (Ertin, 1994: 18). 1984 yılında, yabancı sermaye tarafından kurulan Anadolu Osmanlı Şimendifer Kumpanyası (Yatağan, 2013, s.86) kentin Osmanlı Dönemi'ndeki ilk sanayi kuruluşudur ve hemen kuzeyinde 1950'li yıllara kadar açlan pek çok endüstri tesisinin bulunduğu Fabrikalar Bölgesi'nin gelişiminde belirleyici etmen olmuştur. 1950'lerden itibaren karayolunun demiryoluna üstün hale gelmesine rağmen Eskişehir, Anadolu demiryolu ağında önemli bir kavşak olması sayesinde demiryolu endüstrisindeki gelişimini sürdürmüştür. O dönemki ismi ile Cer Atölyesi kent dokusundaki payını artırmıştır (Ertin, 1994: 52). Yapımına 1953'te başlanan ve 1955'te kullanıma açlan yeni gar binası dönemin mimari dilini yansıtmaktadır ve kentin simge yapılarından biri olmuştur (Koca ve Karasözen, 2010).

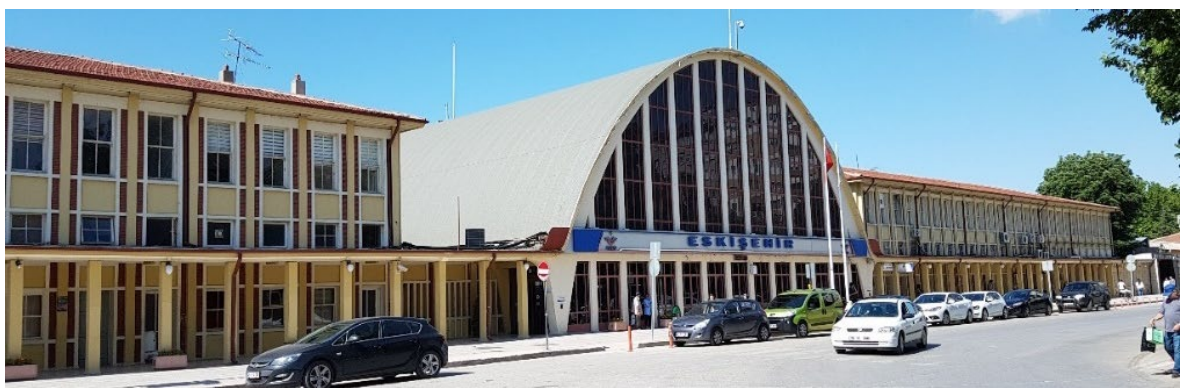

Şekil 6. Eskişehir Gar'ın ön cephesi (Haziran 2018, kişisel arşiv) 
Gar ile kentin eski yerleşim bölgesi olan Odunpazarı' $n$ birbirine bağlayan cadde bugün de önemli ana arterlerden biridir. TÜRASAŞ Eskişehir yerleşkesinin sınırları dışında, yerleşkenin batısında ve demiryolunun güneyinde kalan TCDD Gar Sahası içinde yer alan gar yapısı kolektif bellekteki yerini ve sembolik değerini korumaktadır.

1970'lerden itibaren Eskişehir'de endüstrinin ivmesi ve çeşitliliği artmaya devam etmiştir (Çayır, 2011, s.16-17). Ancak son dönemdeki endüstri tesisleri kentin batısındaki Organize Sanayi Bölgesi'nde konumlanmaktadır. Keleş'e göre (2008), özellikle 2000'li yıllardan itibaren endüstri ve kent merkezinin birbirinden uzaklaştıılması hedeflenmektedir. Sadece bölgeleme temelli bir planlama stratejisi olarak yorumlanabilecek bu yaklaşım kentsel fonksiyonların birbirinden ayrışması, üretim ve kentsel mekânın birbirinden uzaklaşması ve kentin parçalanması gibi olumsuz sonuçlar doğurmaktadır (Keleş, 2008, s.17). Eskişehir'de yeni endüstriyel yapı ve yerleşkeler Organize Sanayi Bölgesi'nde konumlanmakta hatta Kılıçoğlu Tuğla ve Kiremit Fabrikası gibi kentin köklü endüstri yerleşkeleri de üretimlerine bu bölgeye taşıma kararı almaktadır (Bilgin, 2007). Kent merkezinde kimi endüstri mirası işlevini yitirmekte ve dönüşümleri üzerine tartışmaları gündeme getirmekte iken TÜRASAŞ Eskişehir, Sümerbank, Şeker Fabrikası gibi kimi endüstri tesisleri kurulduğu yerde üretimlerine devam etmektedir. Bulunduğu yer ve gelişkinliği sayesinde ile TÜRASAŞ Eskişehir yerleşkesi kent bağlamında önemini hâlen korumaktadır.

\section{Yerleşkenin gelişimi}

TÜRASAŞ Eskişehir yerleşkesi çeperi boyunca süregiden yüksek duvarlar ile çevresinden ayrışmaktadır. Bu sınırın fabrikanın erken dönemlerinde daha parçalı olduğu ve alanın sıklıkla tarımsal alanlar, seyrek yerleşim dokusu, demiryolu ve Porsuk Nehri ile çevrelendiği görülmüştür.

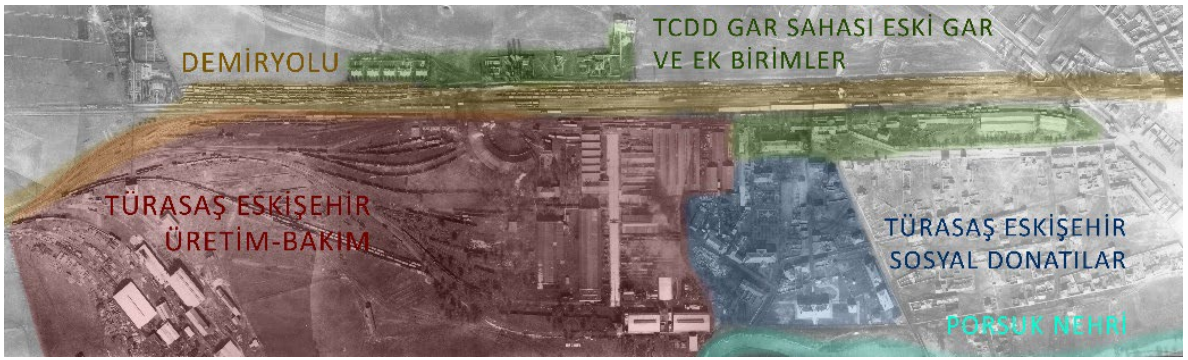

Şekil 7. Yerleşkenin 1935 yılına ait hava fotoğrafından üretilmiştir

(TÜRASAŞ Eskişehir Arşivi, 2018). 


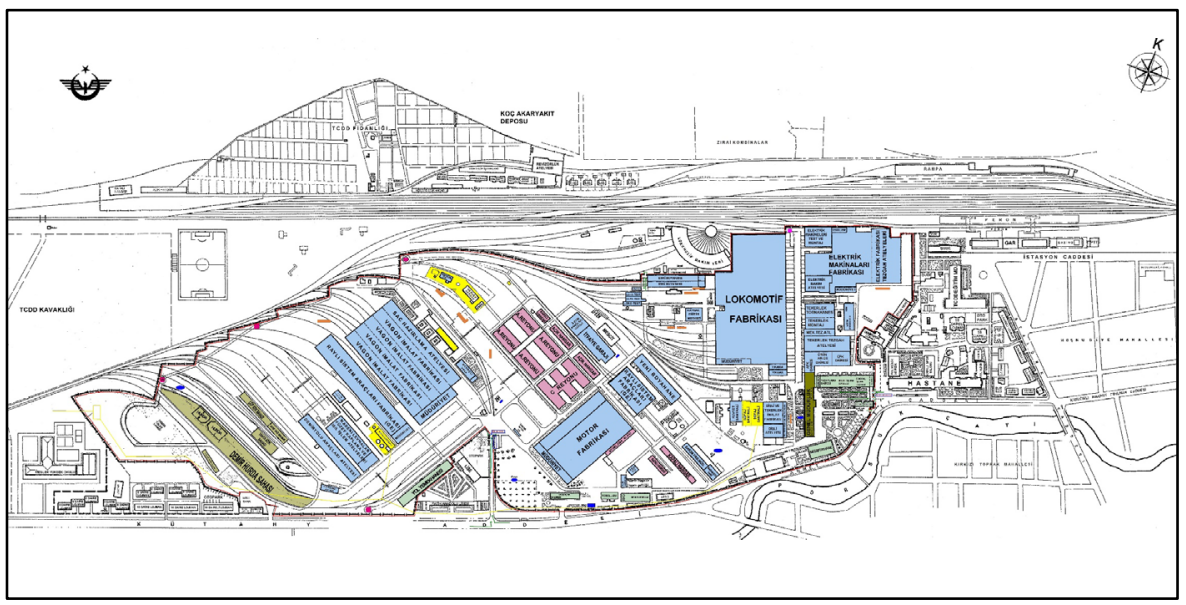

Şekil 8. Yerleşkenin yakın dönem vaziyet planı (TÜRASAŞ Eskişehir Arşivi, 2018).

Bugün, yerleşkeye ait bölgelerin sınırları ilk katmanda katı ve yüksek duvarlar, kısıtlı bir gölümde görsel olarak geçirgen sınır elemanları ile çevrilidir. Kente doğru ikincil katmanda ulaşım yolları ve Porsuk Nehri bölgeyi sınırlandırmaktadır. Yerleşkenin kuzeyi demiryolu, güneyi Basın Şehitleri Caddesi ve Porsuk Nehri, doğusu Atatürk Caddesi, batısı ise TCDD Kavaklığı ve Kütahya Yolu ile sınırlanmaktadır. Farklı ve ayrık bölgeler tanımlayacak biçimde örgütlenen sinırlardan, oldukça sıkı ve kontrollü geçişlere izin verilmektedir. İlk bölge, kurumun öncü sosyal donatılarını ve lojman yapılarını kapsamakta olup, çevresi görsel olarak geçirgen ancak kontrollü sınır elemanları ile çevrilidir. Kentlinin bu alana fiziki olarak dahil olma imkânı yoktur. Sadece tesisin üretim ve teknik birimlerini kapsayan ana bölge ile arasında kalan Demirsoy Sokak'tan gara ve çevresine erişilebilmektedir. Yerleşkenin üretim ve idari birimlerini barındıran alan iki ana kapıya ve ek kapılara sahiptir. Güneyde yer alan müze, misafirhane, alım-satım birimi, spor tesisleri, ortaokul, Porsuk Meslek Yüksekokulu ve Ulaştırma Meslek Yüksekokulu'na kontrollü girişlerin sağlandığı ek kapılar vardır. Bu alanların yerleşkeye komşu sınırları ikincil duvarlara sahiptir, bu duvarlarda yine denetimli kapılar yer almaktadır. 


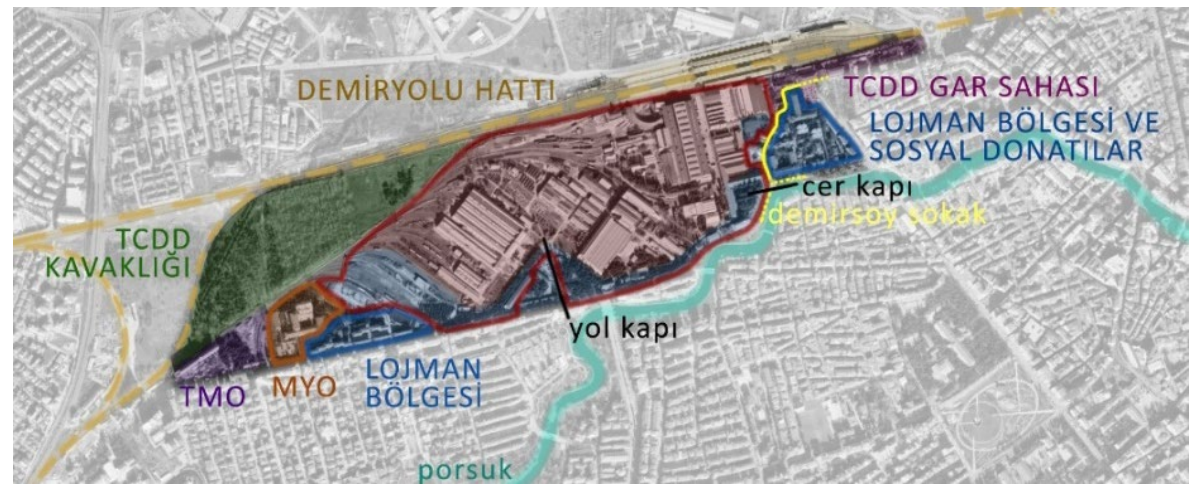

Şekil 9. Yerleşkedeki bölgeler niteliklerine göre işaretlenmiş ve sınır elemanları vurgulanmıştır. Hurdalık, Demirspor Tesisleri, Misafirhane ve okullar yerleşkenin güneyinde bulunmaktadır (Google Earth, 2021).
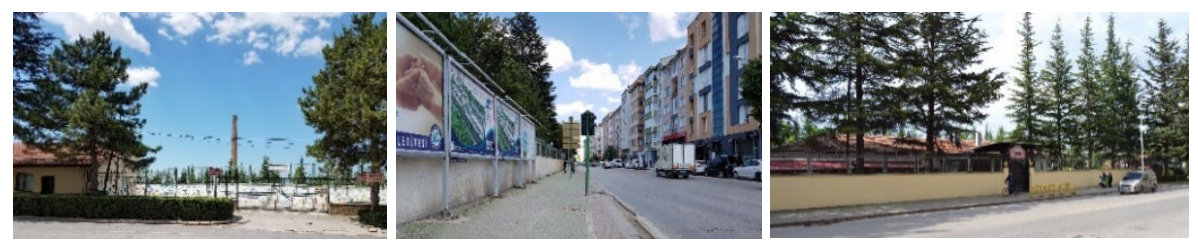

Şekil 10-11-12. Yerleşkenin güney sınırından görünümler. Soldan sağa; Demirspor Tesisleri girişi, Vali Ali Fuat Caddesi ile Basın Şehitleri Caddesinin kesişimin noktasındaki duvar ve panolar, Devrim Arabaları Müzesi girişi (Kişisel Arşiv, 2018).

Bölgenin tamamı endüstriyel miras, endüstriyel peyzaj niteliği taşımaktadır ve bütüncül biçimde ele alınmalıdır. Ancak yerleşkedeki kimi yapı, alan ve donatılar kültürel ve sembolik anlamı bağlamında öne çıkmaktadır. Yerleşkenin ana girişi olan Cer Kapı ve saat kulesi bu bağlamda öne çıkan değerlerden biridir. Kent ve kentli ile kurduğu tarihi bağ, simgesel anlam en azından görsel olarak deneyimlenebilmesi sayesinde hala etkisini sürdürmektedir.
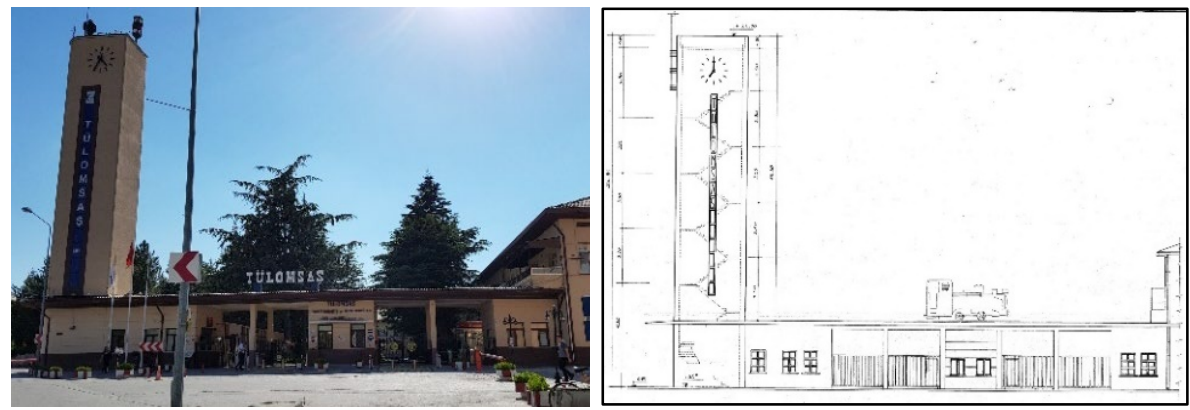

Şekil 13-14. Cer Kapı; güvenlik birimleri ve giriş saçağı ile saat kulesi ve cephe çizimi (Kişisel Arşiv, 2018; TÜRASAŞ Eskişehir Arşivi, 2018). 
Ana kapının kuzey kısmında, fabrikanın sosyal tesisleri; Demirspor Lokali, etkinlik ve spor alanları bulunmaktadır. Bu bölge geçmişte kentin sosyokültürel anlamda dönüşümünün itici güçlerinden olmuştur. Yerleşkenin doğu ve batı ucunda bulunan lojmanlar, açk alanları ve sosyal donatıları dışa kapalıdır ancak geçirgen sınır elemanlarına sahip olduğu için yakın çevresi ile görsel etkileşimini kısmen sürdürmektedir.
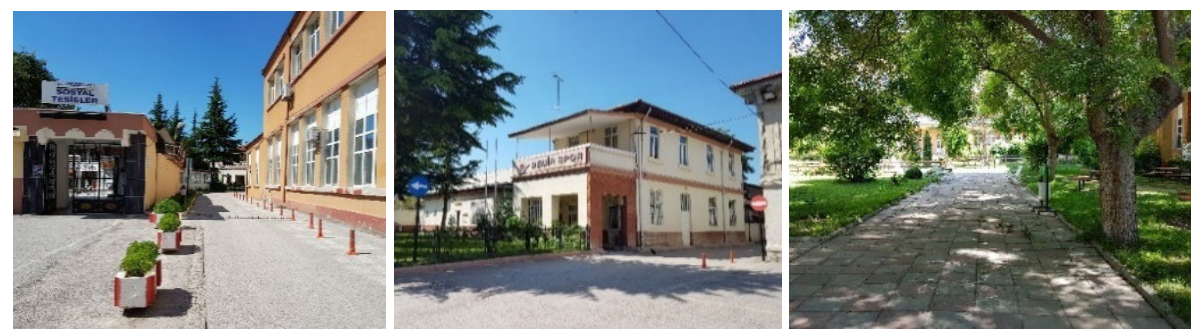

Şekil 15-16-17. Yerleşkenin ana giriş kapısının yanındaki sosyal tesisler, Demirspor Lokali ve en sağda hastanenin arka bahçesi (Kişisel Arşiv, 2018).

Benzer biçimde fabrikanın erken dönem yapılarından Lokomotif Fabrikası, Elektrik Makinaları Fabrikası ve üretim, bakım, onarımına dair çeşitli birimlerin bulunduğu bölge, yine erken döneme ait mimari yapılar ve demiryolu endüstrisine ilişkin tipik yapılardan biri olan dairesel planlı lokomotif deposu (benzer ve önemli örneklerinden biri de Haydarpaşa İstasyonu'nda bulunmaktadır. Detaylı bilgi için bkz.: Yazar ve Binan, 2019), kullanımını hala sürdürmekte olan su deposu (alimantasyon binası) yerleşkenin mimari anlamda öne çıan değerlerindendir.
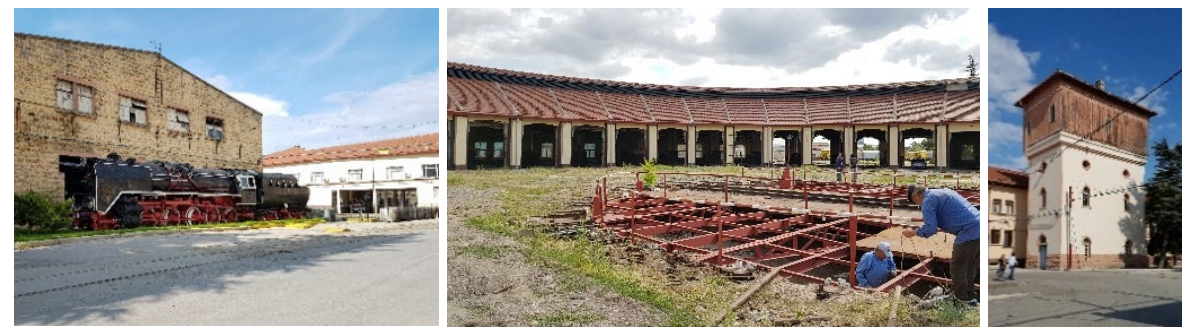

Şekil 18-19-20. Lokomotif Fabrikası ve Karakurt, dairesel planlı lokomotif deposu ve su deposu (Kişisel Arşiv, 2018).

Misafirhane, Devrim Arabaları Müzesi ve TCDD Eskişehir Müzesi kısmen de olsa kent ve kentli ile ilişki kuran alanlardır. Misafirhane ve Devrim Arabaları Müzesi girişleri, yerleşkenin güney sınırında yer alan ve katı sınırın, kontrollü biçimde delindiği noktalardır. 

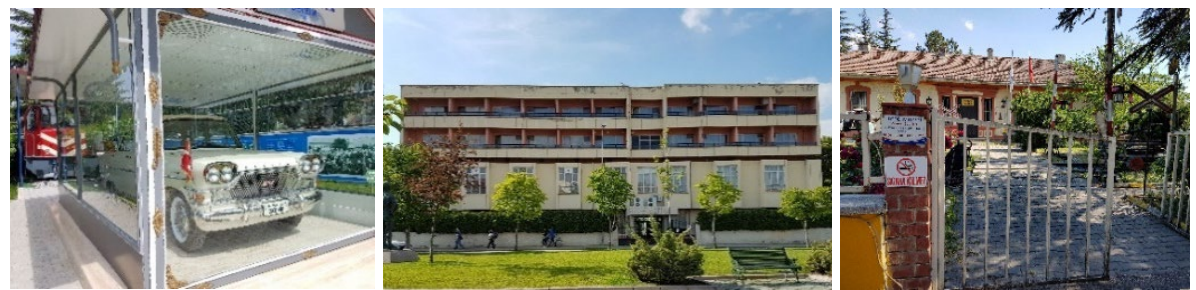

Şekil 21-22-23. Devrim Arabaları Müzesi'nin bahçesinde sergilenen Devrim Arabası, Misafirhane ve gar yakınındaki TCDD Eskişehir Müzesi ve bahçesi (Kişisel Arşiv, 2018).

Demirspor tesisleri ve saha ile hemen yanında bulunan hurdalık ve atık sahası da kent ile iletişim kurulabilecek alanlardır. TCDD Genel Müdürlüğü Arşivi'nden (2. Bölge Müdürlüğü) erişilen (2019), yerleşkenin 1946 yılına ait vaziyet planında bugünkü hurdalık sahasında bir tuğla fabrikası olduğu görülmüştür. Tuğla fabrikasının sadece bacası ayakta kalabilmiştir. Bugün baca ve içinde bulunduğu hurdalık sahası demiryolu endüstrisinde kullanılan ve fabrikadan çıkan pek çok makine ve aracın sergilendiği bir alan halini almıştır. Bu sahada çalışanların emeği ile düzenlenen alanın kentle bir teması bulunmamakta, hatta pek çok kentli gibi fabrikada çalışanların da bu alan ile iletişimi azdır. Yerleşkenin sahip olduğu değerler bahsi geçen tekil yapı örnekleri veya alanlar ile sınırlı değildir, çalışma kapsamında öne çıkan değerlere vurgu yapılmıştır.
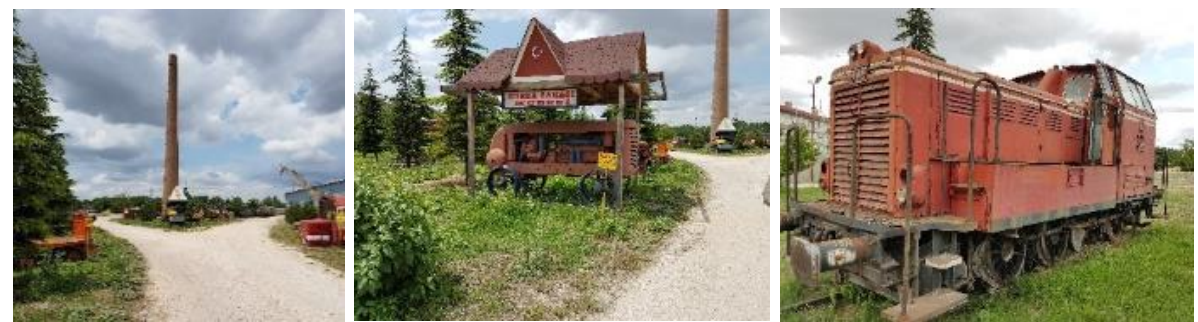

Şekil 24-25-26. Hurdalık sahasından fotoğraflar; sergilenen araçlar ve tuğla fabrikasının bacası (Kişisel Arşiv, 2018).

\section{Yaşam biçimi}

Demiryolunun kente yeni ulaştı̆̆ yıllarda İstanbul'dan gelen trenler bir gece duraklatılmıştır. Tren garı ve yakın çevresinde konaklama yapıları, eğlence mekânları, restoranlar gelişmeye ve bölgenin sosyal hayatı canlanmaya başlamıştır (Güneş ve Yakut, 2007, s.96-98). Demiryolu işçilerine özel işletmelerin açılması, gayrimüslim yerleşimlerinin gelişmesi, farklı fonksiyonlara sahip yapıların gelişimi Eskişehir'in farklı kültürel değerler ile tanışması için önemli gelişmeler olmuştur (Ertin, 1994, s.17-18). 
1923-1950 yılları arasında, üç büyük endüstri tesisinin (DDY Cer Atölyesi, Tayyare Bakım Atölyesi ve Şeker Fabrikası) etkisi ve 1956 yılında Eskişehir Basma Fabrikası'nın (1968 yılında sermaye yetersizliği nedeni ile Sümerbank tarafından devletleştirilmiştir (Ertin, 1994, s.46) açılması ile Osmangazi, Sümer, Ertuğrulgazi Mahalleleri gelişmeye başlamıştır (Ertin, 1994, s.22-25; Keleş, 2008, s.23-24). Bu mahalleler planlıdır, tek veya iki katlı, bahçeli konutların yanında apartman tipi konutların üretildiği de görülmektedir (Ertin, 1994, s.27-28). Özellikle İkinci Dünya Savaşı sonrası ülkenin ekonomik, politik ve toplumsal anlamda yaşadığı değişiklikler sonucunda ivmelenen kentleşme, konut ihtiyacını giderek artırmıştır ve yeni çözüm arayışlarını gündeme getirmiştir. Örneğin, "kooperatifler" aracılığı ile (Turan, 1992) işçi mahallelerinde pek çok konut üretilmiştir. Endüstri kuruluşları sayesinde kentlinin tanıştı̆̆ sinemalar, yeni tip konutlar, bisiklet kullanımı gibi etmenler ile Eskişehir modernleşmiştir (Özkut, 2017). Özellikle 1970'lerde artan araç sayısı ve trafik yoğunluğu nedeni ile bisiklet kullanımı artmıştır (Anadolu Gazetesi, 2019). Fabrikanın ana kapısında bisiklet askılarının hâlen yoğun biçimde kullanıldığı gözlemlenebilmektedir. Bugün, kentlinin de ulaşımda bisikleti yoğun biçimde kullandığı gözlemlenebilmektedir.
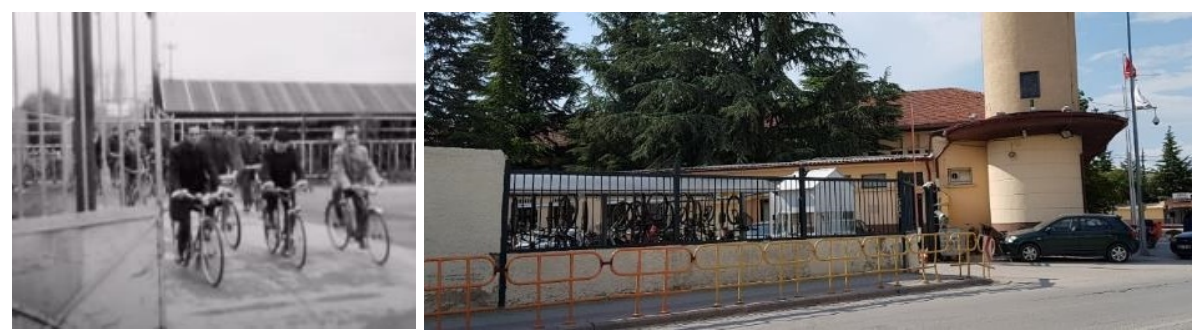

Şekil 27. TRT'nin 1972 yılındaki haberinde, TÜLOMSAŞ işçilerinin sıklıkla bisiklet kullanmayı tercih ettiklerinden bahsedilmiştir (Anadolu Gazetesi, 2019). Şekil 28. Fabrikanın ana giriş kapısındaki bisiklet askıları (Kişisel Arşiv, 2018).

1925 yılından 1980 yılına kadar, personelin cüzi bir kira karşılığında faydalanabileceği lojmanlar inşa edilmiştir ve günümüzde kullanılmaya devam etmektedir. Lojmanlar, yerleşkenin doğu ve batı uçlarında olmak üzere iki ayrı alanda yoğunlaşmıştır. Doğuda, fabrikanın ilk barınma birimlerinin üretildiği lojman bölgesinde az katlı sekiz tip konut bulunmaktadır. Yerleşkenin batısında, özellikle 1970-80 yılları arasında gelişen iki farklı apartman tipinden oluşan lojman bölgesi gelişmiştir (Üstün, 2011). Kuruma ait lojmanlar, geleneksel Türk Evi şemasına uygun biçimde sofalı plan tiplerinden, modernleşmenin konuta ve yaşam biçimine yansıması sonucu gelişen, konut içi 
hacimlerin özelleştiği ve koridorlar ile bağlandığı apartman tipi konutlara kadar farklı örnekler sunmaktadır (Üstün, 2011). Ayrıca miras, konutlardaki konforun gelişmesine de katkı sunmuştur. 1940 yılında Cer Atölyesi'nde üretilen radyatör ve kalorifer kazanları konuttaki konforu artıran bir adım olmuştur (Ekimci, 2016).

1980-1990 yılları arasında işçi mahallerinin genişlemesi ve kooperatifler aracilığı ile konut üretimi sürmüştür, kent merkezinde yükselen nüfus yoğunluğu ile birlikte apartmanların inşası hızlanmış, kat sayıları artmıştır (Ertin, 1994, s.77-78). İş̧̧i kooperatifleri ile fabrikanın işçilere sunduğu lojmanlar kent hakkı bağlamında ayrışmaktadır. 1991 yılında ait hava fotoğrafında kentsel dokunun tüm yönlerde yayıldığı ve bütünleştiği, sanayi kuruluşları yakınındaki mahallelerin, Porsuk'un güney kıyısına da yayıldığı ve Porsuk kıyısındaki tarım alanlarını işgal etmeye başladıkları görülmektedir. O dönemdeki ismi ile TÜLOMSAŞ artık her yönde büyüyen kent dokusuna oldukça yakın, büyük bir yerleşkeye dönüşmüştür.

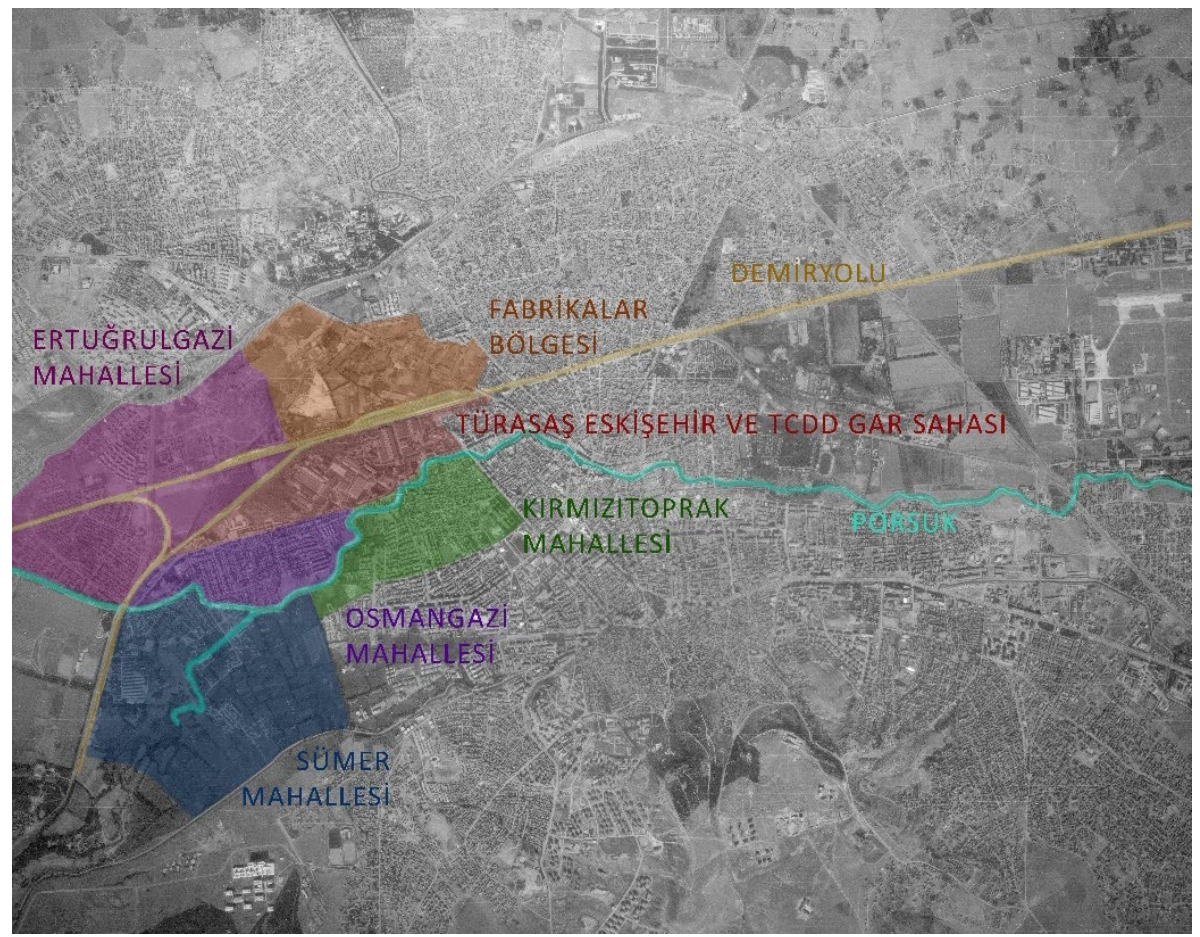

Şekil 29. 1991 yılına ait Eskişehir hava fotoğrafı: TÜRASAŞ Eskişehir'in yerleşkesi, çevresindeki mahalleler ve Fabrikalar görselde vurgulanmıştır (Harita Genel Müdürlüğü Arşivi, 2019). 
Lojman bölgeleri ve fabrika çeperine eklemlenen spor birimleri, park ve çocuk bahçeleri ve çeşitli sosyal etkinliklerin düzenlenebileceği mekânlar ile birlikte sosyokültürel etkinlikler gelişmiştir. Yerleşkenin ana girişine yakın bir hastane çalışanlara ve kentliye hizmet vermiştir, bugün Yunus Emre Devlet Hastanesi'ne bağlı olarak işlevini sürdürmektedir. Demirspor Kulübü ve Toplantı Evi öne çıkan etkinlik ve spor alanlarından olmuştur (Yatağan, 2013, s.59-60). Demirspor Kulübü Tesisleri, 1930 yılında açılmıştır ve güreş, boks ve eskrim gibi sporları da kapsayan açık/kapalı spor alanlarını barındırmaktadır. Demiryolları bünyesinde ilk olarak Eskişehir Demirspor kulübü kurulmuştur (Uçak, 2001). Temelde fabrikada çalışanlarının ve işçilerin spor yapmalarını sağlamak için açılan Demirspor kulüpleri, fabrika sınırlarını aşıp tüm Devlet Demiryolları bünyesine yayılan bir unsur olmuştur (Çanak, 2015). "Demirspor" adıyla kurulan ilk takım olan Eskişehirspor Demirspor, kentin en eski futbol takımı olmasının yanında basketbol, voleybol, bisiklet, atletizm, yüzme, karate gibi branşlara da sahiptir ve pek çok başarısı bulunmaktadır (Bozoğlu, 1997; Eskişehir Demirspor, 2021). Günümüzde hâlen faal olan Demirspor Kulübü kolektif bellekteki yeri, özellikle demiryolu işçilerinin yaşantısındaki rolü nedeniyle son derece önemlidir.

1938 yılında çalışanlara ve ailelerine hizmet eden, kültürel etkinliklerin düzenlendiği "Toplantı Evi” açlmıştır. Fabrikada sosyokültürel etkinlikler, eğlenceler, sinema gösterimleri yapılmıştır. Cumhuriyet'in hedeflediği modern yaşam biçimini kurma anlamında önemli bir yeri olan Toplantı Evi, kentin sosyokültürel dönüşümünde etkili olmuştur (Şenol 1994, s.44-45; Üstün, 2011; Yatağan, 2013, s.59-60, 87). Fabrikanın misafir salonlarında film gösterimleri yapılarak, çalışanların ve ailelerinin faydalanması sağlanmıştır (Şenol 1994, s.44-45; Üstün, 2011).

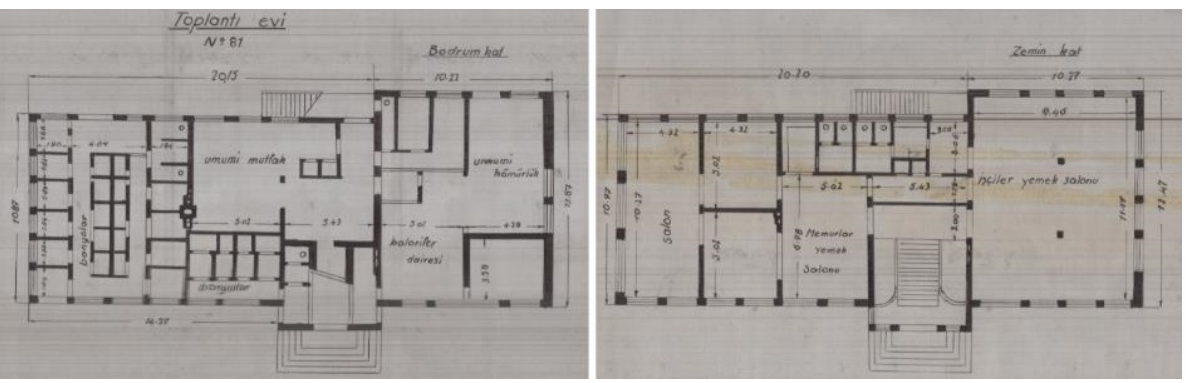

Şekil 30-31. Toplantı Evi'ne ait bodrum ve zemin kat planları (TCDD Genel Müdürlüğü Arşivi, 2019). 


\section{Üretim}

1894 yılında atölyenin açılması ile birlikte kentte işçi grubu ve iş kültürü gelişmeye başlamıştır (Menekşe, 2020). Demiryolu hattının kente gelişi ve Kumpanya'nın açlması ile kent demografik, ideolojik, ekonomik ve kültürel anlamda pek çok dönüşüm yaşamıştır (Ertin, 1994, s.17; Keleş, 2008; Yatağan, 2013, s.110) ve "endüstri kenti" olma yolunda ilk adımlarını atmıştır. Lokomotif ve vagon tamiri hedefiyle kurulan tesis, sonraki dönemde endüstrinin gelişimini ve işçi istihdamını sağlamaya devam etmiştir. I. Dünya Savaşı s1rasında atölye, gar ve çevresi kritik görevler üstlenmiştir (Ertin, 1994, s.18-22).
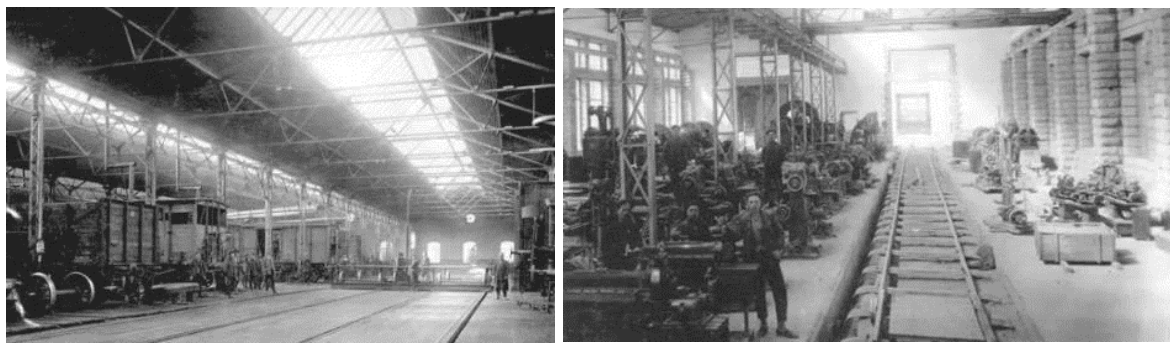

Şekil 32-33. Atölyenin erken dönemlerinden görünümler (Koylu, 2015, s.17-18).

Türkiye Cumhuriyeti özellikle kuruluş döneminde dışa bağımlılığı önlemek için endüstrileşmeye önem vermiştir. Eskişehir'in coğrafi konumu ve Bağdat-Berlin Demiryolu hattında bulunması nedeniyle ülke için önemi giderek artmıştır (Koca ve Karasözen, 2010). II. Dünya Savaşı'nın bitimine hatta 1950’li yıllara kadar kentte, özellikle Cer Atölyesi'nin yakınında endüstriyel alanlar ve kamu yatırımları çoğalmış, kalifiye elemanların yetiştirilmesi sağlanmış ve modern bir kamusallık türetilmiştir (Keleş, 2008, s.23-24, Özkut, 2017). 1923-1950 yılları arasında planlı endüstrileşme dönemi yaşayan Türkiye için Eskişehir, Cer Atölyesi sayesinde önemli bir yer edinmiş ve nitelikli iş gücünün gelişiminde önemli rol oynamıştır (Ertin, 1994: 24-25).

Endüstriyel yapılar ve fonksiyonlar dışında kazandığ 1 farklı eylem ve yapı türleri ile kentin çehresi değişmiş ve kentlinin sosyal yaşamı zenginleşmiştir. Göçmenler, farklı dönemlerde kentin yeniliklerle tanışmasına, kültürel olarak çeşitlenmesine katkıda bulunmuştur. Örneğin 19. yüzyılda Osmanlı'nın göçmen yerleştirme politikası bağlamında Eskişehir'e göç başlamıştır ve böylece kent tarım ve küçük sanayi aletleri ile tanışmıştır (Keleş, 2008). Benzer şekilde, 1950'lerde başta Bulgaristan ve Romanya'dan gelen göçmenler ile yeni yerleşimler gelişmiş ve mahallelerin sınırları genişlemiştir. Göçmenler, kentlinin soba ve kuzine üretimi gibi yeni zanaat biçimlerini tanımasını, böylece metal 
eşya sanayisinin gelişimini sağlamış (Çayır, 2011, s.16; Ertin, 1994, s.41), kentin endüstriyel kimliğine ve mirasına katkı sunmuştur.

Kurulduğu dönemde sadece bakım ve onarım yapan tesis, zaman içinde gelişerek üretim yapabilecek duruma gelmiştir. KIT (Kamu İktisadi Teşebbüsü) halini aldıktan sonra yerel üretimin ön planda tutulması üzerine, 1957 yılında Mehmetçik ve Efe adlı iki adet buharlı lokomotif üretilmiştir. 1961 y1lında, Karakurt isimli ilk yerli lokomotif tamamlanmıştır. Yine 1961 yılında 4,5 ay içinde Deorim Arabaları üretilmiştir, Eskişehir ve Türkiye Cumhuriyeti tarihinde yer edinmiştir (TÜRASAŞ Devrim Arabaları Müzesi, 2021; Yatağan, 2013, s.88). Sonraki dönemde fabrikada yapılan üretimlerin miktarı ve çeşitliliği giderek artmış, yerli imalat oranı da yükselmiştir; dizel motorlar (Bayazit, 1976), dizel elektrikli lokomotifler ve asenkron motorlu lokomotiflerin (Akçasu, 1995) üretilmesinin yanı sıra kayar duvarlı vagon projesi, İstanbul metro araçları projesi, tank motorları projesi gibi pek çok proje tasarlanmıştır (TÜLOMSAŞ Loko, 2000(39), s.9-17, 25). Kurum, temel faaliyet alanlarını bakım/onarım işlemleri ile birlikte farklı tür (dizel hidrolik, dizel elektrikli, elektrikli, hibrit) lokomotifler, yük vagonu, cer motoru, dizel motorları üretimi olarak tanımlamakta (TÜRASAŞ, 2021) ve demiryolu endüstrisi bağlamında bugün de önemini korumaktadır.

\section{Ĕ̆itim}

Hem çalışanların çocuklarının eğitimini karşılamak hem de ihtiyacı olan elemanı yetiştirmek bağlamında, endüstri yerleşkeleri içinde kurulan okullar veya farklı yerlerde eğitim alınabilmesi için verilen destekler bu temel ihtiyacın ne denli önemsendiğinin kanıtıdır. Devletin sağladığı eğitim hizmeti dışında ilk özel eğitim birimlerini ve sistemini geliştiren demiryolu kurumları olmuştur. Temel eğitim ve iş başında yapılan pratik eğitim olarak iki farklı açıdan ele alınan bir sistem kurulmuştur. Çırak okulları bu sistemin en somut örnekleridir (Alanyalıŏlu, 1973).

Süreç içinde TÜRASAŞ Eskişehir yerleşkesinde farklı eğitim kurumları gelişmiştir. Ayrıca yabancı işçilerin çocukları için özel okullar kurulmuştur; Cer Atölyesi'nin kurulduğu ilk dönemde, 1909-1910 yıllarında Almanlar tarafından açılan ve ilköğretim seviyesinde eğitim veren okul (Yakut, 2015, s.62) ve yine yakın dönemde açlan rahibe okulu (Yatağan,2013, s.112) bu okullara örnektir. Atölyenin erken dönemlerinde açlan "Çırakhane", Cumhuriyet Dönemi sonrasında Çırak Mektebi'ne dönüşmüş, fabrikanın en önemli eleman kaynağı olmuştur. Eğitim verilen çocukların ilkokuldan sonra tercihen Çırak Mektebi'ne alınması öngörülmüştür. Okulda spor, resim ve 
müzik salonları, atölye gibi birimler bulunmaktadır ve Almanca yabancı dil eğitimi verilmiştir (Yakut, 2015, s.62). Burada hem kurumun eğitime ve kentlinin gelişimine olan katkısını hem de fabrikanın kuruluşunda etkin olan yabancı ortaklıkların eğitime etkisini görmek mümkündür.
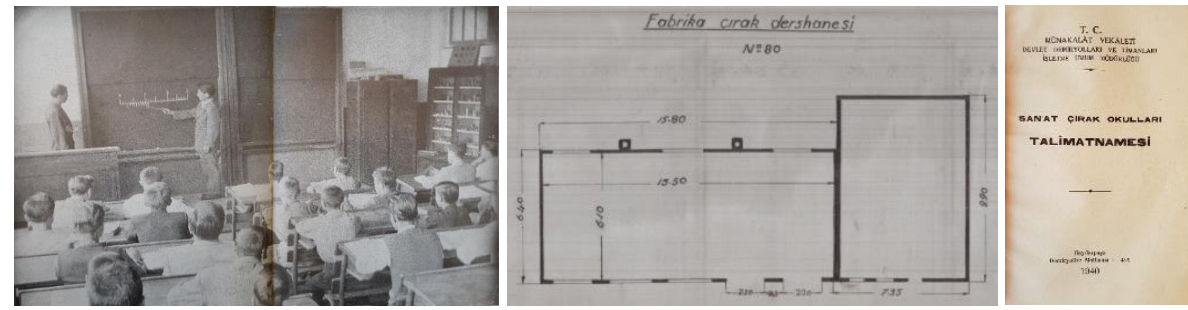

Şekil 34. Çırak okulu öğrencilerinin dersi (Sarı̈z, 1997, s.76-77). Şekil 35. Fabrikanın Çırak dershanesi planı (TCDD Genel Müdürlüğü Arşivi-2.Bölge Müdürlüğü, 2019). Şekil

36. Çırak Okulları Talimatnamesi (TÜRASAŞ Eskişehir Arşivi, 2018).
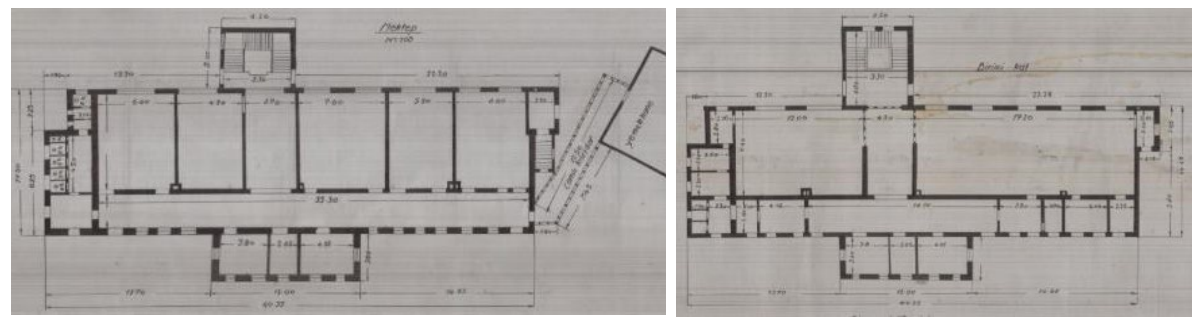

Şekil 37-38. Yerleşkedeki bir okula ait planlar

(TCDD Genel Müdürlüğü Arşivi-2.Bölge Müdürlüğü, 2019).

1946 yılında, Türkiye'de kaynak teknolojisini geliştiren ve ülkede bir ilk olan Kaynak Okulu (Kaynak Evi) yine bu yerleşkede açılmıştır (Akçasu, 1995). Ayrıca Devlet Demiryolları İdaresi, yakınında okul bulunmayan çalışanların çocukları ve akrabalarının eğitim ihtiyacını karşılamak için Eskişehir'de Aile Mektebi açmıştır (Şenol, 1994, s.29-30). Kurum çalışanlarının eğitimleri, kendilerini sürekli geliştirmeleri de önemsenmiştir. Farklı dönemlerde eğitimler, kurslar, seminerler düzenlenmiştir; bu konuda 1976 yılında düzenlenen, mühendis ve teknikerlere çağdaş yönetim tekniklerinin güncel uygulamaları hakkında bilgi edinmeleri için düzenlenen İş Etüdü semineri örnek gösterilebilir (Erdem, 1976). 


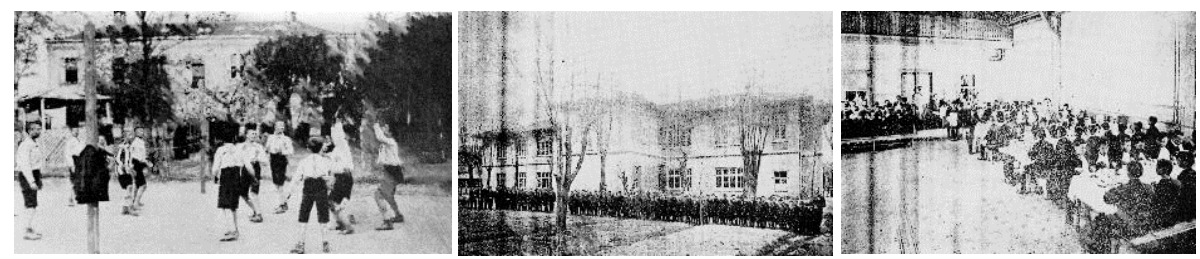

Şekil 39-40-41. Aile Mektebi öğrencileri voleybol oynarken, Eskişehir öğrenci pansiyonu ve yemekhanesi (Şenol, 1994: 30-31).

1979 yılında ülke genelinde meslek ve çırak okullarının kapatılması, mesleki anlamda donanımlı çalışan ihtiyacının artmasına neden olmuştur. Bu ihtiyaç farklı eğitim merkezleri ile karşılanmaya çalışılmıştır. "Dizel makinist yardımcısı", "Yol çavuşu tekâmül” ve "Döner köprü" gibi kursların verildiği Eskişehir Eğitim Merkezi bu duruma örnektir (Mumyakmaz, 1979). Ayrıca 1955-1957 yılları arasında Demiryolu Meslek Okulu ve 1977-1998 yılları arasında Demiryolu Meslek Lisesi Eskişehir'de eğitim vermiştir (Koçkar, 2017). Bugün Eskişehir Teknik Üniversitesi'ne bağlı Porsuk Meslek Yüksekokulu ve Ulaştırma Meslek Yüksekokulu'nun, yerleşkenin batı çeperinde konumlanması ve demiryolu endüstrisi alanında ülkenin önemli eğitim kurumlarından birine dönüşmesi tesadüf değildir, TÜRASAŞ Eskişehir'i geliştirdiği köklü eğitim kültürünün bugüne etkileri olarak görülmelidir.

\section{Kurum kimliği ve niteliği}

1894 yılında "Anadolu Osmanlı Şimendifer Kumpanyast" ismi ile kurulan atölye (Şenol, 1994, s.15), 20 Mart 1920'de "Cer Atölyesi" ismini almıştır (Yatağan, 2013, s.86). II. Dünya Savaşı sonrası yaşanan olumsuzluklar sonrasında 1953 yılında Kamu İktisadi Teşebbüsü (KİT) haline getirilmiş ve 1958 yılında "Eskişehir Demiryolları Fabrikalan" ismini, 1970 yılında ise "Eskişehir Lokomotif ve Motor Sanayii (ELMS)" ismini almıştır. 1986 yılında yeniden yapılandırılarak TCDD bağlı ortağı olarak tanımlanmış ve "Türkiye Lokomotif ve Motor Sanayii A.Ş. (TÜLOMSAŞ)" olarak anılmaya başlamıştır (Yatağan, 2013, s.8789). Son olarak, 04 Mart 2020 'de üç köklü demiryolu tesisinin bir araya getirilmesiyle kurulan Türkiye Rayl Sistem Araçları Sanayii Anonim Şirketi (TÜRA$S A S ̧)$ altında, "TÜRASAŞ Eskişehir Bölge Müdürlüğü" ismini almıştır. Bahsi geçen üç endüstri kuruluşu şunlardır: Türkiye Lokomotifve Motor Sanayii AŞ (TÜLOMSAŞ), Türkiye Vagon Sanayii AŞ (TÜVASAŞ) ve Türkiye Demiryolu Makinaları Sanayii AŞ (TÜDEMSAŞ). Bağlı ortak niteliğinden çıarılan kuruluşlar, "İktisadi Devlet Teşekkülü" olarak kurulan Ankara merkezli yeni kuruluşun bölge müdürlükleri halini almıştır (Resmî Gazete, 2020). 


\section{Kent Hakkına Yansımaları}

TÜRASAŞ Eskişehir'in kent toplumunun oluşumuna etkileri ve tarihi boyunca üretmiş olduğu değerlerin kent hakkı kapsamında yorumlanması için Lefebvre' den hareketle $(2016$, s.116, 151) iki alt başlık önerilmiştir: Öz yönetim hakkı ve sahiplenme hakkı.

\section{Öz yönetim hakkı}

Avrupa Konseyi (Council of Europe, 2005) tarafından Toplum için Kültürel Mirasın Değeri Çerçeve Sözleşmesi'ne, kültürel mirasın yönetim süreçlerine kentlinin katılımı önermesi dahil edilmiştir (Aykan, 2018). Hodder'e göre, her kültürel mirasın içkin özellikleri olduğu ve birbirinden farklılaştığ bireyin kültürel miras ile geliştirdiği bağ kendine özgüdür, eş değerdedir. Bu özgün ilişkiler farklı katılım türlerini gerektirir, her birinin anlaşılması ve adil bir katılımın sağlanabilmesi için iş birliği gerekmektedir (Hodder, 2010). Jacobs, öz yönetimden bahseder ancak içerik olarak kentsel yönetime katılım fikrine daha yakın bir konumdadır. Ona göre kentlerdeki öz yönetim temelde birbirini destekleyen ve bütünleşen üç tür muhit üzerinden kurgulanabilir; bir bütün olarak kent, sokaklar ve semtler (Jacobs, 2011, s.138-146). Ancak bu yaklaşımların hepsi mevcut merkezi otoriteyi kabul etmekte ve karar süreçlerine katılım hakkı ile yetinmektedir. Kademeli, kontrollü, demokratik bir sistem önerisinden ileri geçilememektedir.

Katılım bir başlangıç noktası oluşturabilir ancak öz yönetim daha fazlasını gerektirmektedir. Lefebvre (2016, s.116) için katılım pasif ve daha düşük bir beklentiyi karşılarken, öz yönetim gerçek ve aktif bir eylemliliktir. Endüstrileşme ile dönüşen kenti ele alırken yönetenler ve yönetilenler arasında yeni bir etkileşim biçiminin, yani karar verici özneler ve nesneler arasındaki ilişkinin gözden geçirilmesi gerektiğini vurgulamıştır (Lefebvre, 2016, s.143). Bu noktada öz yönetimi sanayinin de öz yönetimini kapsayan politik bir devrim, genelleşmesi gereken bir sistem olarak görülmelidir (Lefebvre 2014, s.16; Lefebvre 2016, s.160). Merkezi yönetim ile ona karşı direnme gücüne sahip yerel iktidarların (belediye, eyaletler, bölgeler) karşı karşıya gelmeleri tabandan yönetime yani öz yönetime dair çeşitli imkanları barındırmaktadır. Ancak birbirlerini sönümledikleri bir döngü oluşturma ihtimali de vardır (Lefebvre, 2014, s.379, 382). En önemlisi taban baskısının (sendikalar, hak talepleri, grevler) toplumun çıkarlarına, ihtiyaçlarına yönelik etkin kullanımı ve dayatılan tüm unsurlara karşı sürdürülmesidir (Lefebvre, 2014, s.382, 383). 
Eskişehir'de hem TÜRASAŞ Eskişehir özelinde, öz yönetimi elde etmeye ilişkin çeşitli örgütlerden bahsedilebilmektedir: Eskişehir Kent Konseyi, Tepebaşı Sağlıklı Kent Konseyi ve Odunpazarı Kent Konseyi, Eskişehir İş Konseyi gibi konseylerin yanında Raylı Sistemler Teknolojisi Mezunları Derneği (RESTDER), Demiryolu Meslek Okulu Mezunları Derneği Eskişehir Şubesi (DEMOK), Raylı Sistemler Kümelenmesi (RSC), Demiryol-İş Sendikası Eskişehir Şubesi gibi teşkilatlar bulunmaktadır. TÜLOMSAŞ'ın kapatılması ve diğer TCDD bağlı ortakları ile birlikte merkezi Ankara' da olacak TÜRASAŞ’a dahil edilmesi sonrasında, yerleşkenin 1/1000 imar planının hazırlanması için ihale açılmıştır (Rayhaber, 2020).

İsminin ve tüzel kimliğinin değiştirilmesi, imar planlarının hazırlanması gibi adımlar sonucunda fabrikanın özelleştirilmesi, taşınması veya kapatılması endişeleri doğmuştur. Sözü geçen konsey, dernek, oluşumların bir kısmı ve miras ile doğrudan ilişkisi bulunmayan kimi oluşum bir araya gelerek endişelerini, görüşlerini ve taleplerini dile getirmişlerdir. Yapılan açıklamada yerleşkenin kent/kentli için önemi üzerinde durulmuş, alanla ilgili değişikliklerde kentlinin söz sahibi olması gerektiği vurgulanmıştır (Hacıoğlu, 2020). Hareket yeterli güce erişememiş, daha çok katılıma yönelik talepler gündeme getirilmiştir. Yine de TÜRASAŞ Eskişehir özelinde beliren önemli bir eylemdir ve kent hakkına yönelik bir başlangıç oluşturabileceği nedeni ile değerlidir.

TÜRASAŞ Eskişehir'in sahip olduğu temel güçlerden biri üretimdir. Merkezi yönetime bağlı şekilde üretim yaptığ1 için kentsel yaşama bu üretimin dahil olma ihtimali yoktur. Sadece kurumda çalışanların dahil olabildiği, bu dahil oluşun da yine çalışma, boş vakit, ikamet mekanlarının ayrı oluşu (Lefebvre, 2014, s.87) üzerinden kurulduğu bir üretim vardır. Hem üretimin hem de onun eğitime, yaşam biçimine yansımalarının kent toplumunun gündelik hayatına dahil olması gerekmektedir.

\section{Sahiplenme hakk}

Kent hakkına dahil olan sahiplenme, mülkiyet hakkından farklıdır (Lefebvre, 2016, s.151). Kentsel mekâna hatta zamana, kentte yaşayanlar tarafindan el konulmasıdır; "yaşama, oynama, çalı̧ıma, onda temsil edilme, onu tanımlama ve işgal etme" haklarını kapsamaktadır (Aktaran Sadri, 2005, s.79-80). Bu sahiplenme modeli; kentin bir yapıt olması, diğer sanatlar ile kent ve kentsel yaşamın iç içe geçmesi olarak açklanabilir (Lefebvre, 2016, s.150-151). Lefebvre'in tanımı herhangi

\footnotetext{
${ }^{1}$ Oluşumlar hakkında bilgi için bkz.: Eskişehir Kent Konseyi, 2021; Tepebaşı Sağlıklı Kent Konseyi, 2021; Eskişehir Odunpazarı Kent Konseyi, 2021; Eskişehir İş Konseyi, 2021; RESTDER, 2021; DEMOK, 2021; RSC, 2021; Demiryol-İş Sendikası, 2021.
} 
bir kentteki tüm çeşitliliği kapsayarak, belki de şimdiden tahayyül edilemeyecek tüm olasılıkların önünü açmaktadır. Bu hedefe erişilebilmesi için öncesinde birkaç adıma ihtiyaç olabileceği düşünülmektedir. Çünkü burada önemli olan kentlinin farkındalığıdır. Tüm bileşenleri ile kendisini, kent toplumunu, kenti tanımalı, neden sahiplenmesi gerektiğinin bilincinde olmalıdır. Bu noktada modern kent üzerine geliştirilen düşünümlerden ve kentli haklarından alınan destekle ilk adımlar atılarak, Lefebvre'in arzu ettiği sahiplenme için bir başlangıç noktası oluşturulabilir.

Çalışmanın kapsamı gereği endüstri mirası özelinde farkındalığın gelişimi için ilk koşut kentli ve mirasın hem fiziki hem sosyokültürel anlamda karşılaşma alanlarını artırmaktır. Bunun için miras ve kentli arasındaki etkileşimi kesintiye uğratan fiziki ve sosyal sınırların eritilmesi gerekmektedir. Mirasın fiziki sınırları yerleşkenin gelişimi başlı̆̆ında da irdelendiği üzere kentli ile iletişimin ilk kırıldığ katmandır. Jacobs'ın deyimiyle pasif bir eleman olarak görülen sınır aslında kent ve kentli üzerinde aktif bir etkiye sahiptir (Jacobs, 2011, s.276). Sinırın niteliğinin, gerekliğinin, olumlu ve olumsuz yönlerinin sorgulanması (Jacobs, 2011, s.276) ve çözümün alanın niteliğine göre belirlenmesi gerekmektedir. Jacobs (2011, s.284-288) sınırın niteliğine ve problemlerine yönelik çeperin daha fazla kullanılmasını sağlamak, farkl kullanım tipleri sunmak, sinıra yakın olan nüfus yoğunluğunu kontrol etmek gibi öneriler sunmaktadır. TÜRASAŞ'ın sahip olduğu farklı sınır tiplerinin gerektiği veya mümkün olduğu yerlerde ve oranda daha geçirgen hale gelmesi ile başlanabilir.

Ayrıca kentlinin erişimine, kullanımına açılması mümkün olan bölgeler veya yapılar, gündelik hayatın barındırdığı sosyal karşılaşmaları artıran yeni ortak kullanım alanları oluşturulabilir. Harvey'e göre (2013, s.117-119), özel mülkiyetin güç kazanması ve kentsel müşterek alanların giderek azalması sonucunda ortak mülkiyete sahip kaynak ve kentsel mekânların hem bireysel hem de kolektif biçimde faydacıl kullanımını sağlayacak yeni yöntemler geliştirilmelidir. Bu bağlamda gündeme gelebilecek "kamusal mekânlar" ile "kamu yararı için ortak alanlar" arasında önemli farklar vardır: Kimin çkarları doğrultusunda oluşturulduğu, korunduğu, denetlendiği ve kime fayda sağladığı, bu imkanlara erişimin nasıl gerçekleştiği bu tanımları birbirinden ayıran önemli kriterlerdir (Harvey, 2013: 123-125).

Ağırlıklı olarak yerleşkenin kuzeyinde yer alan demiryolu hattına yakın konumlanan üretim ve riskli alanların güneyini kent ile daha sıkı etkileşim kurabilecek biçimde dönüştürülebilir. Yerleşkenin güney hattı boyunca yer alan Demirspor tesisleri, okullar ve yemekhane binasl, bugünkü TÜRASAŞ Devrim Arabaları Müzesi ve yakın çevresi, kurum misafirhanesi ve alanda çalışanların 
çabası ile âdeta açık hava müzesine dönüşen hurdalık sahası kent ve kentli ile etkileşime girebilecek alanlardır. Ayrıca sosyal tesisler, her iki lojman bölgesi ve onlara ait sosyal donatılar da kentli ile etkileşimin güçlenmesi anlamında potansiyelli alanlardır. Bu alanlar içinde hurdalık, çalışanların kurumu ve alanı sahiplenmesinin ve kendi çabaları, istekleri ile dönüştürmeleri açısından önemli bir örnektir.

$\mathrm{Bu}$ alanlar, kurumun erken dönemlerinde kentli daha güçlü bir etkileşim içinde olduğu ve kentlinin dönüşümünde de aktif rol aldığı için kolektif bellek açısından da önemlidir. Bulunduğu çevreyi üreten doğrudan kendisi olmasa bile orayı sahiplenen, kolektif belleğe ait unsurların benimseyen gruplar gelişmektedir. Böylece sahiplenilen mekânın dönüşümü söz konusu olduğunda veya dönüşüm dayatıldığında grup direnç gösterebilmekte (Halbwachs, 2018, s.165166), kent hakkı talebine dair potansiyeller belirebilmektedir. Daha önce sözü edilen, TÜRASAŞ’ın geleceğine ilişkin kaygıların dile getirildiği hareket bu duruma örnek verilebilir.

Assmann, anıların gerçekleştikleri zaman ve mekânlar ile hatırlandığını, fiziki unsurların bellekte sembolik anlamlar edindiğini vurgulamıştır. Grup, kimliğini ve iletişim biçimlerini kuran, kolektif anılarının dayanağı olan mekânlar üreterek varlığını sağlamlaştırmaktadır (Assmann, 2015, s.46-47). Halbwachs, salt fiziki ortamların değil sosyal, kültürel, tarihsel tüm somut ve somut olmayan diğer ortamların da bellekte etkili olduğunu belirtmiştir (Halbwachs, 2018, s.165-166). Harvey tarafindan önerilen, kolektif belleğe ait unsurların kentlinin gündelik hayatına dahil edilmesi fikri "bellek hakkı"; anımsanan geçmişi bugüne dahil ederek, "geleceğin hatıralarını" oluşturma talebi olarak yorumlanabilir (Yelsalı Parmaksız, 2019). Bu tanımlar kapsamında TÜRASAŞ Eskişehir kent siluetindeki etkisi, özellikle yerleşkenin gelişimi başlığında aktarılan simge yapıları ve nitelikli mekanları, sosyokültürel birimleri ve etkinlikleri, önemli üretimleri gibi kentli tarafindan sahiplenilen değerleri aracılığ ile kolektif bellekte yer edinmiştir.

Kentsel mekân dilsel veya metinsel çağrışımları ile kolektif bellekteki yerini güçlendirmekte ve toplumla ilişki kurmaktadır (Arslan ve Uludağ, 2020). Connerton (2014, s.20-24), mekânsal belleği "anıt mekân ve mahal" olarak ikiye ayırmış ve anıt mekânı yer isimleri, kutsal yolculuklar ile açıklamıştır. Yer isimleri sadece konum belirtmek için değil, oraya ait niteliklerin vurgulanması ve kolektif bellekte yer edinmesi anlamında oldukça önemlidir. Bu noktada TÜRASAŞ Eskişehir'e tarihi boyunca farklı isimler verilmesi kolektif belleği etkilemiştir. "TÜLOMSAŞ", tarihi boyunca uzun yllar koruduğu isimlerden biri olmuştur, bu nedenle yakın dönemde kurumun ismi değişmiş olsa dahi kentli tarafindan kulla- 
nılmaya devam etmektedir. İsim değişiklikleri kimi zaman zorunluluktan kaynaklansa dahi her değişim mirasın kimliğini ve kolektif bellekteki yerini etkilemektedir. Benzer biçimde Osmangazi Mahallesi'nde bulunan "Demiryolcu ve Behiç Beyler" gibi sokak isimleri ile yerleşkenin ana girişinin "Cer Kapı" olarak anılması, kurumun ürettiği değerlerden temellenmekte ve kentlinin kolektif belleğindeki yerini sürdürmektedir.

\section{Tartışma ve Sonuç}

Endüstriyel yapılar/yerleşkeler kentlerde belirdikleri andan itibaren eski şehirlerin dönüşmesine neden olmuş, bugünkü kenti ve bir bütün olarak kent toplumunu inşa etmiştir. Süreç tek taraflı değildir. Kentli de endüstriyel yapı/yerleşkeyi üretmiş ve onu bir yapita dönüştürmüş̧ür. Bu etkileşim ne kadar güçlü ise endüstriyel yapının/alanın endüstri mirasına dönüşme ihtimalinin o kadar arttığı söylenebilir. Sanayileşmenin ve kentleşmenin sorunları endüstri mirası üzerinde de baskı kurmaktadır. Her şeyi ürüne dönüş̧türen ve mübadele değeri ile ölçen sistem, bu yapıtı da bir meta olarak dönüştürmeye çalışmaktadır. Burada kritik iki aşama vardır. İlki mirasın işlev yitimi ve çöküntü alanına dönüşmesinden sonra yapıttan kalanlar ile ne yapılacağının belirlenmesidir. İkincisi ise bu kararı kimin vereceğinin belirlenmesidir.

Çalışma, sözü geçen kritik süreçlerin hemen öncesine odaklanarak iki sorunun da yanıtını aramaktadır. Endüstri mirasının kentin gelişim sürecindeki etkileri ve kentli ile arasındaki güçlü ilişki nedeniyle Lefebvre'in kent hakkı kavramı yol gösterici olmuştur. TÜRASAŞ Eskişehir özelinde mirasın tüm bileşenleri ile birlikte kent toplumunun oluşumundaki önemi, etkileri sorgulanmıştır. Bu etkilerin bir kısmının yok olduğu, bir kısmının olduğu gibi korunduğu, bir kısmının ise dönüsserek bugüne kadar varlığını sürdürdüğü söylenebilir. Mirasın kentsel dokuya olan mekânsal etkileri (çeperindeki yerleşimlerin gelişimi, ana arterlerin oluşumu, kent siluetine etkisi gibi) büyük oranda aynı şekilde sürmektedir. Kentlinin sosyokültürel yaşamına etkisi (eğitim, üretim, eğlence gibi) kısmen azalmakta ve dönüşmüş halde varlığını sürdürmektedir. Örneğin Devrim Arabalarının üretildiği tarihteki etkisi ile bugün Devrim Arabaları Müzesi'nde ziyaret edildiğindeki etkisi birbirinden oldukça farklıdır. Geçmişte bu kurumda üretilmiş bir değeri korumak ve yine burada ziyaretçilerin erişimine sunmak önemlidir. Öte yandan bu ziyaretin turistik gerekçeleri ve ziyaretçi üzerindeki etkisi ile o üretimin yapıldığı dönemde miras ve kentli arasında gelişen etkileşimin birbirinden farklı olduğunu söylemek mümkündür.

Son olarak mirasın yok olan, bugüne aktarılamayan değerlerinden de söz edilebilir. Örneğin süreç içinde yıkılan nitelikli yapılar, kapanan eğitim kurumları 
bugüne aktarılamayan değerlerdendir. Şüphesiz mirasın kuruluşundan bugüne tüm değerlerini eksiksiz koruması mümkün değildir. Ancak kentli ve miras arasındaki etkileşimi güçlendiren ve kentli için önemli olan değerlerin korunması sağlanmalıdır. İşlevini kaybetmeden mevcut yerinde varlığını ve dönüşümünü sürdürmesi bu nedenle önemlidir. Böylece kentlinin mirası daha güçlü sahipleneceği, geleceği konusunda karar vericinin kendisi olması gerektiğini fark edeceği ve bu gücü elde etmeye yönelik somut adımlar atacağı öngörülmektedir.

Burada sözü edilen Lefebvre'in kent hakkı tanımının sürekliliğinde bir güç talebidir. Ancak bu tanımın mevcut koşullar içinde anlaşılması veya uygulamaya geçirilmesi zordur. Bu noktada kısmen kentli hakları bağlamında değerlendirilebilecek müdahaleler ile yola çıkmak süreci hızlandırabilir. Örneğin, kentlinin nitelikli değerlere sahip olan yerleşkeyi yerinde deneyimleyebilmesi ve kişisel olarak tanıklık etmesi, kentlinin farkındalığını geliştirebilecek bir adımdır. Mevcut durumda üretimin gizliliği, sürekliliği ve güvenlik sebepleri ile yerleşkenin her alanının kamuya açılması mümkün değildir. Ancak sosyal mekânlar başta olmak üzere kısmi ve periyodik biçimde kentliye açılması mümkün olabilir. Avrupa'da sıklıkla karşılaşıldığı gibi endüstriyel yerleşkelerin açı kapı uygulaması ile üretimi aksatmayacak biçim ve sıklıkta ziyaretçilerin fabrikanın işleyişini, üretimini ve nitelikli mekânların yerinde deneyimlemesine olanak tanınabilir. Burada önemli olan, Devrim Arabaları hususunda değinildiği gibi bu değerlerin salt turizm nesnesine, Lefebvre'in deyimiyle (2016, s.27) "estetik bir haccın ve turistik bir tüketimin alanı" haline dönüşmesinin önüne geçmektir. Bunun için belki bir ziyaretten ötesi, mirasın kentsel yaşama da dahil olabileceği kurgular üzerine düşünmek gerekebilir.

TÜRASAŞ Eskişehir özelinde iki hareket öne çkmaktadır: İlki, hurdalık sahasının çalışanların emeği ile fabrikadan çıkan endüstriyel donatıların, ürünlerin sergilendiği bir alana dönüştürülmesidir. İkincisi, yakın dönemde kurum kimliğinin değişmesi ile yükselen endişelere karşı çeşitli örgütlerin bir araya gelerek mirasa yönelik bir çağrıda, talepte bulunmasıdır. Henüz yeterli güçte ve kapsamda olmasa dahi bu hareketler mirasın kentli ile etkileşim içinde olduğunun, kentlinin onu sahiplendiğinin kantıdır. Miras ile kentlinin karşılaşma alanları artırıldıkça sahiplenme duygusunun güçleneceği, kent hakkına yönelik hareketlerin daha güçlü ve giderek daha geniş kapsamda gelişeceği öngörülmektedir.

\section{Teşekkür}

Yazarlar, arşiv taraması ve yerinde gözlem aşamalarında yardımcı olan tüm TÜRASAŞ Eskişehir Bölge Müdürlüğü ve TCDD Genel Müdürlüğü (2. Bölge Müdürlüğü, Ankara) çalışanlarına teşekkür eder. 


\section{Extended Abstract}

\section{Reevaluating the Industrial Heritage in the Context of the Right to the City: The Case of TÜRASAŞ Eskişehir}

\author{
Ebru Yetkin \\ ORCID: 0000-0001-9614-0355
}

\author{
Esin Boyacioğlu \\ ORCID: 0000-0001-7407-1336
}

\author{
Ayşe Duygu Kaçar \\ ORCID: 0000-0002-6561-7517
}

The term of the right to the city, which is defined as a collective right, has such a wide scope that it proposes a new urban life style, beyond the democratic use of the values in the physical environment where the citizens live. The term emphasizes the right of the citizens to have a say on all tangible and intangible values that the city produces and possesses. Although it is a holistic definition of right, discussion of the parameters it covers is important in terms of identifying and concretizing the equivalents of the right to the city. In this context, industrial sites that enable the development of the city and its citizens are directly related to the right to the city.

Today, due to factors such as land rent, private ownership, tourism potential, etc. of industrial heritage, transformation projects and approaches that care about financial profits are preferred rather than considering the demands of the citizens for the heritage. Decisions to be taken regarding the future of an industrial heritage may irreversibly affect the values of the heritage and its relationship with the city and inhabitants. In order to take into account the wishes of the citizens in the decision processes, the citizens should be aware of their rights to heritage and strongly demand these rights. At this point, the study investigates the relationship between the concepts of industrial heritage and right to the city through a case. TÜRASAŞ Eskişehir site, the first industrial institution of the city, was chosen as the case. The historical process that the site has witnessed since 1894 and the layered relations it has developed with the city, its inhabitants and even the society in this process provide a lot of data to carry out the discussion aimed at the study. A case study was 
conducted on TÜRASAŞ with the data obtained through literature research, archive scanning and on-site observation.

In addition, the fact that the selected case is a featured site that still maintain its function distinguishes it from the sites that have lost their function and are waiting to be transformed. Hence, it is possible to observe its relations with the city and inhabitants even today. Furthermore, it is possible to investigate problems and potentials since it sustains original function and the physical environment in which it was established. Suggestions developed in this context may strengthen the integration with the city and its inhabitants and prevent it from losing its values. With the establishment or strengthening of integration, it is aimed to develop the awareness and consciousness of the citizens about the heritage.

The first stage of the study is to investigate the values that the case site has produced since its establishment and to examine the relationship forms that have transformed over time with the inhabitants. Thus, the effects of the heritage on the city and its inhabitants, and the tangible and intangible values of the heritage were discovered. These values were interpreted under the headings of "self-management and appropriate" within the scope of Lefebvre's definition of the right to the city. In addition, the demands for the right to the city about the heritage are discussed. The values discovered in the context of the right to the city of TÜRASAŞ Eskişehir site are defined under six headings: urban context, development of the industrial site, lifestyle, production, education, corporate identity. Some of the values of the heritage site have disappeared and some still continue their existence in the same way or by transforming. TÜRASAŞ Eskişehir has a high potential to produce new values through its place in social memory.

At the same time, the demands for the right to the city about the heritage were examined. In 2020, the name and status of the institution was changed. various non-governmental organizations, associations and councils have come together and stated that they are against these changes and are worried about the future of the heritage. This movement is considered important because there is a demand for the right to the city about TÜRASAŞ Eskişehir. It was also observed that the scrap yard area of the industrial site was converted by the workers there. The workers ensured that the machine parts, various railway vehicles and industrial equipment discarded from the factory were exhibited in this area where they were afforested. This situation has been found important in terms of appropriating the heritage and transforming it by those who produce it. 
It has been suggested to ensure that it sustains its existence and original function in place, to make its socio-cultural opportunities open to the citizens, to make the production and featured spaces experienceable for visitors through applications such as open doors. In addition, regions where citizens can be involved and shared urban areas can be created have been identified. In this way, it can be ensured that the weakening interaction between the heritage site, the city and the citizens is strengthened again, that the citizens embrace the heritage more strongly and demand their aforementioned rights. These suggestions are partly more closely related to the rights of the citizens. Although it is accepted that these rights are different from the content of Lefebvre's right to the city, they are considered as a phase in order to reach his target. The study reminds the priority of the citizens of the city, who are the real owners of the heritage, which is ignored in the decision processes regarding the future of the industrial heritage. A unique perspective has been developed in the context of the right to the city for the case.

\section{Kaynakça/References}

Akçasu, S. (1995, Şubat). TÜLOMSAŞ Türk demiryolu taşımacilığının lokomotifidir. Anahtar, 8-9.

Alanyalığlu, A. (1973, Kasım). Sosyal kalkınmada demiryolu. Demiryol, 574, 13-14.

Anadolu Gazetesi (2019, 1 Şubat). Eskişehir'de 1972 yılında trafiğe bisikletli çözüm. http://www.anadolugazetesi.com/video/eskisehir-de-1972-yilinda-trafige-bisikletli-cozum.html adresinden erişildi.

Arslan, S. ve Uludağ Z. (2020). Dilde mekânı (yeniden) kurgulamak: Yer isimleri, kolektif bellek ve ideoloji. İdealkent, 11(31), 1422-1455. doi:10.31198/idealkent.829867.

Assmann, J. (2015). Kültürel bellek: eski yüksek kültü̈rlerde yazı, hatırlama ve politik kimlik (2. Bs.). (Ayşe Tekin, Çev.). İstanbul: Ayrıntı Yayınları. (Orijinal eserin yayın tarihi 1997).

Aykan, B. (2018). Kültürel miras hakkı: Kültürel mirasa insan hakları temelli güncel yaklaşımlar. Alternatif Politika, 10(2), 231-252.

Bayazıt, Z. (1976, Ocak). Eskişehir Lokomotif ve Motor Sanayii Müessesesi'nin gelişmesine toplu bir bakış. Demiryol, 600, 7-12.

Bilgin, D. C. (2007, 4 Eylül). Atatürk'ün 'rezil olmayalım' diye kurdurduğu fabrika törenle kapandı. Hürriyet Gazetesi. https://www.hurriyet.com.tr/gundem/ataturkun-rezil-olmayalim-diye-kurdurdugu-fabrika-torenle-kapandi-7213812adresinden erişildi.

Bozoğlu, C. N. (1997, Mart). Eskişehir Demirspor Kulübü. Demiryolu, (3), 22.

Cengizkan, N. M. (2006). Endüstri yapılarında yeniden işlevlendirme: "Iş"i i biten endüstri yapıları ne "iş"e yarar? Dosya 3: Endüstri Mirası, Bülten 45, 9-13. 15 Mayıs 
2021 tarihinde http://www.mimarlarodasiankara.org/dosya/dosya3.pdf adresinden erişildi.

Christensen, P. H. (2017). Germany and the Ottoman railways: art, empire, and infrastructure. New Haven and London: Yale University Press.

Connerton, P. (2014). Modernite nasıl unutturur (2. Bs.). (Kübra Kelebekoğlu, Çev.). İstanbul: Sel Yayıncllık. (Orijinal eserin yayın tarihi 2009).

Çanak, E. (2015). Devlet Demiryollarında sportif faaliyetler ve Adana Demirspor Kulübü. Ç.Ü. Sosyal Bilimler Enstitüsü Dergisi, 24 (1), s.1-12.

Çavuşoğlu ve Strutz, (2011). Editörlerinden. Eğitim Bilim Toplum Dergisi, 9(36), ss.7-13.

Çayır, C. (2011). Sanayi mirasının korunarak yeniden işlevlendirilmesi Eskişehir Fabrikalar Bölgesi Çift Kurt Kiremit ve Tuğla Fabrikası örneği, Yüksek Lisans Tezi, Mimar Sinan Güzel Sanatlar Üniversitesi, İstanbul.

Demiryol-İş Sendikası - Türkiye Demiryolu İşçileri Sendikası Eskişehir Şubesi (2021). 15 Haziran tarihinde https://www.demiryolis.org.tr/sendikamiz/subelerimiz/ adresinden erişildi.

DEMOK- Demiryol Meslek Okulu Mezunları Derneği (2021). 15 Haziran tarihinde http://www.demok.org/category/haberler/sube/eskisehir/ adresinden erişildi.

Ekimci, B. (2016). Erken Cumhuriyet Dönemi mimarlığında Eskişehir'de apartman tipi konutlar (1923-1965). Şerife Geniş ve Emir Osmanoğlu (Der.), II. Uluslararası Kent Araştırmaları Kongresi Bildiriler Kitabı, Küresel ve Yerel Arasında Kentler: Stratejiler, Fırsatlar ve Sorunlar içinde (s. 473-493), İdeal Kent Yayınları: İstanbul.

Erdem, İ. H. (1976, Temmuz). ELMS'de eğitim ve öğretim faaliyetleri. Demiryol, 606, 7.

Ertin G. (1994). Eskişehir kentinde yerleşmenin evrimi. Eskişehir: Anadolu Üniversitesi Yayınları.

Eskişehir Demirspor (2021). Eskişehir Demirspor tarihçe. http://web.archive.org/web/20200222230716/http://www.eskisehirdemirspor.com/tarihce.html adresinden erişildi.

Eskişehir İş Konseyi (2021). 15 Haziran tarihinde http://eskisehiriskonseyi.com/ adresinden erişildi.

Eskişehir Kent Konseyi (2021). 15 Haziran tarihinde https://www.eskisehirkentkonseyi.org.tr/ adresinden erişildi.

Eskişehir Odunpazarı Kent Konseyi (2021). 15 Haziran tarihinde https://www.instagram.com/kentkonseyiodunpazari/ adresinden erişildi.

Google Earth (2021). Eskişehir 2021 hava görüntüleri. 30 Haziran tarihinde https://earth.google.com/web adresinden erişildi.

Güneş, İ. ve Yakut, K. (2007). Osmanlı'dan Cumhuriyet'e Eskişehir (1840-1923). Eskişehir: Anadolu Üniversitesi Yayınları.

Hacıoğlu, C. (2020, 16 Ağustos). Eskişehir halkı belirlemeli. 2 Eylül. https://www.2eylul.com.tr/gundem/eskisehir-halki-belirlemeli/41718 adresinden erişildi. 
Halbwachs, M. (2018). Kolektif bellek. (Zuhal Karagöz, Çev.). İstanbul: Pinhan Yayınc1lik. (Orijinal eserin yayın tarihi 1950).

Harita Genel Müdürlüğü Arşivi (2019). 1991 yılına ait Eskişehir hava fotoğrafı. Ankara.

Harvey, D. (2013). Asi şehirler, şehir hakkından kentsel deorime doğru (3. Bs.). (Ayşe Deniz Temiz, Çev.). İstanbul: Metis Yayınları. (Orijinal eserin yayın tarihi 2012).

Hodder, I. (2010). Cultural Heritage Rights: From Ownership and Descent to Justice and Well-being. Anthropological Quarterly, 83 (4), 861-882. 15 May1s tarihinde https://www.jstor.org/stable/40890842 adresinden erişildi.

İstikbal Gazetesi (2019, 19 Temmuz). TÜLOMSAŞ taşınsın. http://www.istikbalgazetesi.com/haber18.asp?sec=1\&newscatid=7\&yazarid=0\&newsid=209464 adresinden erişildi.

Jacobs, J. (2011). Büyük Amerikan şehirlerinin ölümü ve yaşamı. (Bülent Doğan, Çev.). İstanbul: Metis Yayınları. (Orijinal eserin yayın tarihi 1961).

Kaçar, A. D. ve Alpan, A. (2018). The revival of the industrial heritage in EskisehirTurkey through the rehabilitation of the Porsuk River. GBER Special Edition 2018, 86-100. 25 Mayıs tarihinde https://globalbuiltenvironmentreview.co.uk/journal-articles/specialedition/ adresinden erişildi.

Keleş, R. (2008). Sanayi politikaları ve kentler. Türkiye Mimarlık Politikası'na Doğru Mimarlık ve Kent Buluşmaları (28-29 Temmuz 2007) içinde (ss. 15-24). Ankara: TMMOB Mimarlar Odası.

Koca G. ve Karasözen R. (2010). 1945-1960 dönemi Eskişehir modern kent merkezinin oluşumunda öne çıkan yapılar. Anadolu Üniversitesi Sosyal Bilimler Dergisi, 10(3), 191-211.

Koçkar, Ö. M. (2017, Nisan). Ulaşım kenti: Eskişehir ve ulaştırma eğitimi. Eskişehir Ticaret Odası Dergisi 2017, 82-86. 5 Haziran tarihinde http://www.etonet.org.tr/uploads/201705-ETODergi.pdf adresinden erişildi.

Koylu, Z. (2015). Esaretten özgürlüğe 423 gün, İngiliz işgalinde Eskişehir (3. Bs.). Eskişehir: Eskişehir Ticaret Odası Yayınları.

Koylu, Z. ve Birgün, M. (2015). Eski bir şehrin hikayesi 1923-1938. Eskişehir: Eskişehir Ticaret Odası Yayınları.

Lefebvre, H. (2000). Writings on cities. Oxford/UK: Blackwell.

Lefebvre, H. (2014). Mekânın üretimi (2. Bs.). (Selim Sezer, Çev.). İstanbul: Sel Yayınc1lik.

Lefebvre, H. (2015). Kentsel devrim (4. Bs.). (Işık Ergüden, Çev.). (Orijinal eserin yayın tarihi 1970).

Lefebvre, H. (2016). Şehir hakkı. (Işık Ergüden, Çev.). İstanbul: Sel Yayıncılık. (Orijinal eserin yayın tarihi 1967).

Marcuse, P. (2014). Reading the right to the city. City, 18(1), 4-9. DOI:

10.1080/13604813.2014.878110

Mayer, M. (2011). Kentsel toplumsal hareketlerde "kent hakkı" (Aytaç Demirci, Çev., Erbatur Çavuşuğlu, Düzelti). Eğitim Bilim Toplum Dergisi, 9(36), 153-182. 
Menekşe, M. (2020). Eskişehir' de kolera salgını: Etkileri ve alınan önlemler (1893). Tarih ve Gelecek Dergisi, 6 Sayı 1, 52-88. 25 Mayıs tarihinde https:/www.idealonline.com.tr/IdealOnline/lookAtPublications/paperDetail.xhtml?uId=109084 adresinden erişildi.

Mengüşoğlu, N. ve Boyacıoğlu, E. (2013). Reuse of industrial built heritage for residential purposes in Manchester. METU JFA, 30(1), 117-138. DOI: 10.4305/Metu.Jfa.2013.1.7

Mumyakmaz, H. (1979, Nisan). Demiryollarında yaygın eğitim. Demiryol, 639, 6-8.

Öner, R.V. ve Osmanoğulları, F. (2017). Kentli haklarına karşı şehir hakkı: farklılıklar, benzerlikler ve eğilimler. Emek Araştırma Dergisi (GEAD), 8(11), 75-98.

Özkut, D. (2017). Eskişehir'de modern hafızanin yerel izleri. TÜBA-KED 16, 35-66. DOI: http://dx.doi.org/10.22520/tubaked.2017.16.002

Palmer, M. ve Neaverson, P. (2001). Industrial archaeology principles and practice. New York ve Kanada: Routledge, Taylor \& Francis Group. (Orijinal eserin yayın tarihi 1998).

Rayhaber (2020, 17 Ağustos). TÜLOMSAŞ Arazisi Ranta Kurban Edilir Mi? https://rayhaber.com/2020/08/tulomsas-arazisi-ranta-kurban-edilir-mi/ adresinden erişildi.

Resmî Gazete (2020). Türkiye Raylı Sistem Araçları Sanayii Anonim Şirketi'nin Kuruluşuna İlişkin Karar (4 Mart 2020). 30 Mayıs tarihinde https://www.resmigazete.gov.tr/eskiler/2020/03/20200304-14.pdf adresinden erişildi.

RESTDER-Raylı Sistemler Teknolojisi Mezunları Derneği (2021). 15 Haziran tarihinde http://www.rstder.org/ adresinden erişildi.

RSC- Eskişehir Raylı Sistemler Kümelenmesi (2021). 15 Haziran tarihinde http://www.rsc.org.tr/indextr/ adresinden erişildi.

Sadri, H. (2005). Kent hakkından kentte insan haklarına. Belgin Çınar (Haz.), Kentsel Dönüşüm ve İnsan Hakları içinde (ss. 73-85). İstanbul: Bilgi Üniversitesi Yayınları.

Sarı̈̈z, P. (1997). Bir zamanlar Eskişehir. İstanbul: ESBANK.

Seda, S. (2012, 10 Temmuz). TÜLOMSAŞ taşınmalı. Anadolu Gazetesi, http://www.anadolugazetesi.com/makale/tulomsas-tasinmali adresinden erişildi.

Souza, M. L. (2010). Which right to which city? In defence of political-strataegic clarity. Interface: A journal for and about social movements, 2 (1): 315-333. 25 Mayıs tarihinde https://www.rrojasdatabank.info/desouza2010.pdf adresinden erişildi.

Stuart, I. (2012). Identifying industrial landscapes. J. Douet (Der.), Industrial Heritage Re-tooled: The TICCIH guide to Industrial Heritage Conservation içinde (ss. 48-54). Lancaster: Carnegie Publishing.

Şenol, S. B. (1994). Türkiye demiryollarında 100 Yıl: 1894-1994. Eskişehir: Etam A.Ş. Matbaa Tesisleri.

TCDD Genel Müdürlüğü Arşivi (2. Bölge Müdürlüğü) (2019). Fabrikanın çırak dershanesi planı, Toplantı Evi'ne ait planlar ve yerleşkedeki bir okula ait planlar. Ankara.

Tekeli, İ. (2015). Kent, kentli hakları, kentleşme ve kentsel dönüşüm (2. Bs.). İstanbul: Tarih Vakfı Yurt Yayınları. 
Tepebaşı Sağlıklı Kent Konseyi (2021). 15 Haziran tarihinde https://www.instagram.com/tepebasisagliklikent/ adresinden erişildi.

Turan, N. (1992). Konut sorununun çözümünde bir alternatif olarak konut kooperatifleri ve Eskişehir ilindeki konut kooperatiflerinin sosyo-ekonomik analizi. Doktora Tezi, Anadolu Üniversitesi, Eskişehir.

TÜLOMSAŞ LOKO (2000, Temmuz). TÜLOMSAŞ’in tarihi hukuki statüsü ve kapasitesi. (39), 9-17, 25.

TÜRASAŞ (2021). Eskişehir Bölge Müdürlügü. 30 Mayıs tarihinde https://www.turasas.gov.tr/eskisehir-bolge-mudurlugu adresinden erişildi.

TÜRASAŞ Devrim Arabaları Müzesi (2021). İlk yerli buharlı lokomotif "Karakurt". 30 Mayıs tarihinde http://devrimarabasi.com.tr/karakurt-lokomotifi/ adresinden erişildi.

TÜRASAŞ Eskişehir Arşivi (2018). Çırak Okulları talimatnamesi, yerleşkenin 1935 y1lına ait hava fotoğrafı, yerleşkenin vaziyet planı. Eskişehir.

Uçak, H. İ. (2001). Demiryollarında sportif faaliyetler ve Ankara Demirspor Kulübü. Kebikeç, 11, 283-294.

Uzunçarşılı Baysal, C. (2011). Kent hakkı yeniden hayat bulurken. Eğitim Bilim Toplum Dergisi, 9(36), 31-55.

Üstün, B. (2011). Eskişehir Devlet Demir Yolları yerleşkesi lojman konutları plan tipolojileri üzerine bir çalışma. Tasarım+Kuram, 7 (11), 40-66. 5 Haziran tarihinde https://www.tasarimkuram.com/tr/jvi.aspx?un=DTJ-59354 adresinden erişildi.

Yakut, K. (2015). Modern Eskişehir'in Doğuşu (1923-1938). Eskişehir: Kebikeç Yayınları.

Yatağan, N. (2013). Cumhuriyet Dönemi endüstri yapıları ve modernleşme ilişkileri üzerine bir inceleme: Eskişehir TÜLOMSAŞ yerleşkesi, Yüksek Lisans Tezi, Dokuz Eylül Üniversitesi, İzmir.

Yazar, N. E. ve Binan, C. S. (2019). Haydarpaşa İstasyonu Dairesel Planlı Lokomotif Deposu'nun Koruma Olasıllkları. Megaron, 14 (2), 254-268. DOI: 10.14744/MEGARON.2019.52724

Yelsalı Parmaksız, P. M. (2019). Belleğin mekânından mekânın belleğine: Kavramsal bir tartışma. Ankara Üniversitesi İlef Dergisi, 6 (1), 7-26. DOI: 10.24955/ilef.574436 